\title{
Anabases
}

ANABASES Traditions et réceptions de l'Antiquité

33 | 2021

Varia

\section{Lisa Maurice, Screening divinity}

Mathieu Scapin

\section{OpenEdition}

Journals

Édition électronique

URL : https://journals.openedition.org/anabases/12273

DOI : 10.4000/anabases. 12273

ISSN : 2256-9421

\section{Éditeur}

E.R.A.S.M.E.

\section{Édition imprimée}

Date de publication : 10 avril 2021

Pagination : 287-288

ISSN : 1774-4296

\section{Référence électronique}

Mathieu Scapin, « Lisa Maurice, Screening divinity», Anabases [En ligne], 33 | 2021, mis en ligne le 10 avril 2021, consulté le 05 décembre 2022. URL : http://journals.openedition.org/anabases/12273 ; DOI : https://doi.org/10.4000/anabases. 12273 

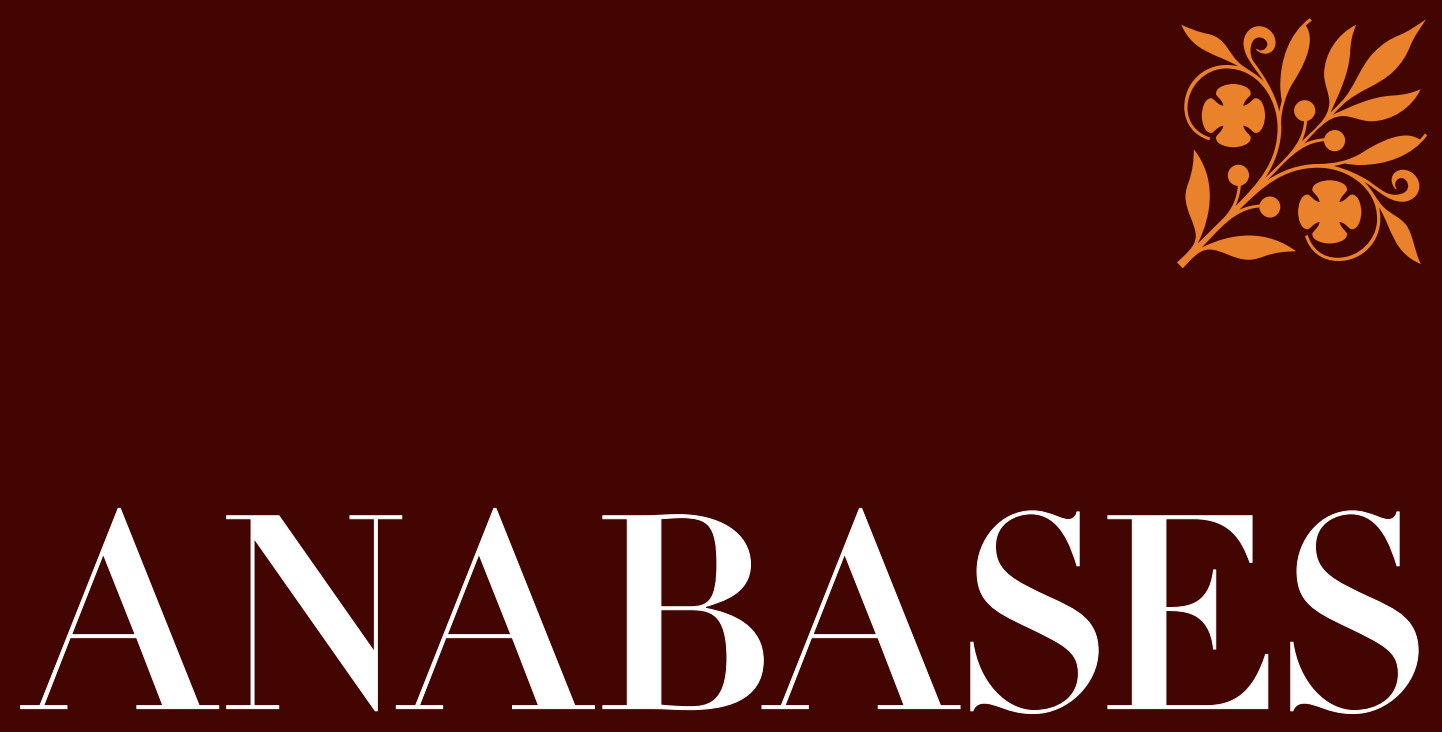

Traditions et Réceptions de l'Antiquité

\section{No33 \\ 2021}

La tragédie grecque entre théâtre et cinéma Sénèque le tragique en Europe, de la fin de l'âge classique au romantisme Les liens scientifico-mondains de Bernard Roy Les Phéniciens d'après Giorgio Levi Della Vida 
ANABASES

Traditions et Réceptions de l'Antiquité

Revue de l'équipe de recherche E.R.A.S.M.E.

Université Toulouse-Jean Jaurès (UT2J)

Anabases dispose d'un Comité de lecture international. Chaque article envoyé à la rédaction est soumis, une fois anonymisé, à l'expertise de deux spécialistes qui rendent un rapport écrit. Les deux rapports anonymisés sont transmis à l'auteur qui tient compte des observations en vue de la publication.

\section{Comité SCIENTIFique}

Germaine Aujac (université Toulouse-Jean Jaurès : histoire de la géographie et des sciences antiques)

Florence Bouchet (université Toulouse-Jean Jaurès : littérature médiévale)

Hinnerk Brunns (CNRS : histoire économique et sociale ancienne et contemporaine)

Paulo Butti de Lima (université de Bari : historiographie et réception de l'Antiquité)

Luciano CANFora (université de Bari : littérature et histoire anciennes, historiographie)

Giovanna Ceserani (Stanford University : histoire intellectuelle et historiographie de la tradition classique)

Temístocles Cezar (université de Porto Alegre : historiographie moderne)

Serafina Сuомо (University of London, Birkbeck College : histoire des mathématiques et des sciences)

Paul Demont (université de Paris Sorbonne : philologie grecque et héritage classique)

Marie-Laurence Desclos (université de Grenoble II : philosophie de l'Antiquité)

Olivier Devillers (université de Bordeaux 3 - Michel-de-Montaigne : littérature et historiographie latines)

Andrea Giardina (Istituto italiano di scienze umane : histoire du monde romain et de ses réceptions)

Ève Gran-Aymerich (AIBL : histoire de l'archéologie et des transferts culturels)

François Hartog (EHEss : historiographie ancienne et moderne)

Geneviève Hoffmann (université de Picardie : histoire des mondes grecs)

Christian JACOB (CNRS/EHESS : histoire comparée et épistémologie des savoirs)

Suzanne Marchand (Louisiana State University : histoire du classicisme et de l'orientalisme)

Wilfried NIPPEL (Humboldt Universität Berlin : histoire et historiographie de l'Antiquité)

Sylvie Pitria (université de Paris I-Panthéon Sorbonne : histoire et historiographie du monde romain)

Stéphane Ratтi (université de Franche-Comté - Besançon : philologie et héritage latin)

Comité de RÉdACtion

Clément Bertau-Courbières, Corinne Bonnet, Laurent bricault, Clément Bur, Adeline Grand-Clément, Anne-Hélène Klinger-Dollé, Véronique Krings, Thibaud Lanfranchi, Pascal Payen, Grégory Reimond, Sarah Rey, Catherine Valenti, Noémie Villacèoue

Éditeur RESPONSABLE

Clément Bur

Éditrice ADJOINTE

Catherine VALENTI

Sites WEB

http://plh.univ-tlse2.fr

Revues.org : http://anabases.revues.org

Aвonnement et vente aU numéro

Éditions De Boccard - 4, rue de Lanneau - 75005 Paris

info@deboccard.com - www.deboccard.com

Tél. : 0033/(0)143260037 - Fax : 0033/(0)143548583 


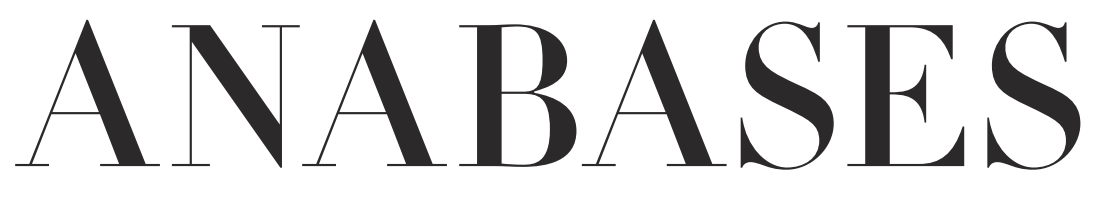

Traditions et Réceptions de l'Antiquité

$$
\begin{aligned}
& N \circ 33 \\
& 2021
\end{aligned}
$$





\section{Sommaire}

$\mathrm{N}^{\circ} 33-2021$

\section{Traditions du patrimoine antique}

\section{Philippe Brunet}

Scène et hors-scène : la tragédie grecque entre théâtre et cinéma II

Dossier Sénèque coordonné par Sylvie Humbert-Mougin

Sénèque le tragique en Europe, de la fin de l'âge classique au romantisme 25

Sylvie Humbert-Mougin

Introduction. En haine de Sénèque le tragique : formes, enjeux et limites

d'un discrédit, de la fin de l'âge classique au romantisme

Florence de CAIgnY

Les tragédies de Sénèque à la fin du xviı ${ }^{\mathrm{e}}$ siècle :

métamorphose d'un modèle théâtral $4 \mathrm{I}$

Pascale Paré-Rey

L’œuvre tragique de Sénèque au XvıII ${ }^{\mathrm{e}}$ siècle :

lectures, relectures et controverses 55

Zoé Schweitzer

La traduction comme réflexion critique sur l'art dramatique?

Jeux et enjeux des tragédies complètes de Sénèque en français

au tournant des XVIII $^{\mathrm{e}}$ et XIx $^{\mathrm{e}}$ siècles (Coupé, I795 et Levée-Duval, I822)

Sylvie LE Mö̈L

Le modèle de Sénèque et la dramaturgie de la fureur

dans le théâtre allemand des Lumières : Gotter et Klinger 
Vincenza Perdichizzi

Alfieri, Sénèque le tragique et le défi de Mérope $\ldots \ldots \ldots \ldots \ldots \ldots \ldots$. II5

\section{Archéologie des savoirs}

Houcine JAÏDI

Les liens scientifico-mondains de Bernard Roy avec les sociétés savantes de Bourgogne, d'Algérie et de Tunisie aux $\mathrm{xIx}^{\mathrm{e}}-\mathrm{xx}^{\mathrm{e}}$ siècles ....... i33

\section{Actualités et débats}

Perikles Christodoulou

Évocations de l'Antiquité dans la Maison de l'Histoire européenne :

sujets, objets, muséographie, muséologie

\section{Lire, relire la bibliothèque des sciences de l'Antiquité}

Maria Giulia Amadasi Guzzo

Les Phéniciens d'après Giorgio Levi Della Vida .................. 2I7

Giorgio Levi della VIDA

“Fenici », dans Enciclopedia Italiana di Scienze Lettere

e Arti, tome XIV, г932, p. 997-1002 . . . . . . . . . . . . . . . . 23І

Gustavo A. Vivas García

El trabajo de Syme sobre Cornelio Galo publicado en ig38 :

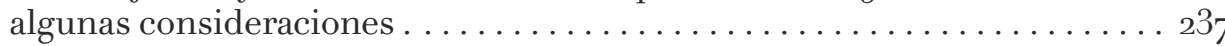

\section{Ateliers}

Atelier « Laboratoires du politique » (5) (coord. P. Butti di Lima)

Maria das Gracias De Moraes Augusto

Politeia tropicale. La presenza del pensiero greco

nella formazione politica del Brasile ottocentesco . . . . . . . . . . 25I

Atelier « L'Antiquité au musée » (10) (coord. A. Grand-Clément)

Dimitri Tillo d’Ambrosi

“ Pompéi » au Grand Palais. . . . . . . . . . . . . . . . . . . . . . . . . 257

Atelier des doctorants (18) (coord. A. Grand-Clément)

Aurore DericQ FacchinetTI

L’Antiquité au kaléidoscope de la traduction : les multiples vies

des Vies de Suétone, de la Renaissance aux Lumières. . . . . . . . . . . . 262 


\section{Comptes rendus}

Marlène Albert-Llorca et Pierre Rouillard

La Dame d'Elche, un destin singulier.

Essai sur les réceptions d'une statue ibérique (Grégory Reimond). . . . . . . . 27I

Antón Alvar Nuño

Historiografía de la esclavitud (Élodie Guillon) . . . . . . . . . . . . . . 273

Federica Bessone et Marco Fucecchi (éds.)

The Literary Genres in the Flavian Age. Canons,

Transformations, Reception (Amedeo Alessandro Raschieri) . . . . . . . . 275

Marco Buonocore (éd.)

Corpus inscriptionum Latinarum. Inscriptiones Calabriae

Apuliae Samnii Sabinorum Piceni Latinae. Supplementum.

Regio Italiae quarta. VolIX. Suppl. Pars I. Fasc. I

Corpus inscriptionum Latinarum. Inscriptiones Calabriae

Apuliae Samnï Sabinorum Piceni Latinae. Supplementum.

Regio Italiae quarta. Vol IX. Suppl. Pars I. Fasc. 2, (Federico Santangelo) . . 277

Marco Cavalieri, Olivier Latteur (dir.)

Antiquitates et Lumières. Étude et réception de l'Antiquité romaine

au Siècle des Lumières (Arnaud Saura-Ziegelmeyer) . . . . . . . . . . . . . . . 279

Jean-Michel David, Frédéric Hurlet et Martin Jehne (dir.)

« La culture politique de la République romaine. Die politische

Kultur der römischen Republik », dans Trivium, 3I, 2020

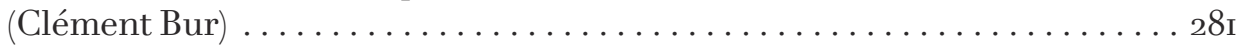

Stephen L. Dyson

Archaeology, ideology and urbanism in Rome

from the grand tour to Berlusconi (Filippo Carlà-Uhink) . . . . . . . . . . . . 283

Alexandra Eckert et Alexander Thein (éds.)

Sulla. Politics and Reception (Cyrielle Landrea) . . . . . . . . . . . . . . 286

Lisa Maurice

Screening divinity (Mathieu Scapin). . . . . . . . . . . . . . . . . . . . 287

Friedrich Meins

Paradigmatische Geschichte: Wahrheit, Theorie und Methode

in den Antiquitates Romanae des Dionysios

von Halikarnassos (Yehudah Gershon) . . . . . . . . . . . . . . . . . . . . . 289 
Pier Giuseppe Michelotтo

Da Pietroburgo a New Haven. Sei saggi su M.I. Rostovtzeff

(Corinne Bonnet) ................................. 290

Astrid MöLLER (éd.)

Historiographie und Vergangenheitsvorstellungen

in der Antike (Louis Autin) . . . . . . . . . . . . . . . . . . . . . . . 292

Helmut Pfeiffer, Irene Fantappiè, Tobias Roth (éds.)

Renaissance Rewritings (Séverine Tarantino) . .................... . 294

Charlayn von Solms

A Homeric Catalogue of Shapes.

The Iliad and Odyssey Seen Differently (Clarisse Evrard) . . . . . . . . . . 295

Trinidad Tortosa (éd.)

Patrimonio arqueológico español en Roma.

“Le Mostre Internazionali di Archeologia de IgII y I937

como instrumentos de memoria histórica (Grégory Reimond). . . . . . . . . . 297

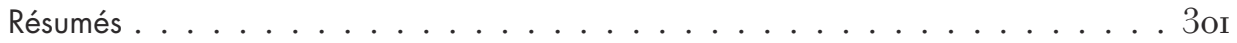

Index . . . . . . . . . . . . . . . . . . . . 307 


\section{Comptes rendus de lecture}



Marlène Albert-LlorCa et

Pierre Rouillard, La Dame d'Elche, un destin singulier. Essai sur les réceptions d'une statue ibérique, Madrid, Casa de Velázquez, 2020, I79 p., I9€/ ISBN 9788490963203.

Il est des objets hérités du passé qui, en raison de leur signification historique ou de l'imaginaire collectif qu'ils contribuent à nourrir, sont revêtus d'une forme de sacralité. La Dame d'Elche en fait partie. L'enquête de Marlène Albert-Llorca et de Pierre Rouillard consiste précisément à étudier les multiples discours auxquels ce chef-d'œuvre de l'art des Ibères a donné lieu: discours savants, celui des archéologues et des érudits, discours de valorisation identitaire, usages sociaux et politiques dont elle fut - et est toujours l'objet. Signalons au passage que les premiers résultats de ce travail avaient donné lieu à la publication d'un article : Marlène Albert Llorca, Jesús Moratalla et Pierre Rouillard, « Le singulier destin d'une sculpture ibérique: la Dame d'Elche», Images Re-vues. Histoire, anthropologie et théorie de l'art, I5, 2018 [en ligne].

Rappelons d'abord quelques faits. Le buste en pierre d'une femme richement parée est découvert par des ouvriers agricoles à La Alcudia, près d'Elche, le 4 août I897. Pedro Ibarra, un érudit local membre de la famille du docteur Manuel Campello auquel appartient le terrain sur lequel on a découvert la sculpture, est le premier lettré à pouvoir l'admirer et à comprendre qu'il s'agit d'une œuvre exceptionnelle. Quelques jours plus tard, l'archéologue bordelais Pierre Paris arrive dans la ville et engage des négociations pour que le musée du Louvre puisse en faire l'acquisition. Rondement menée, l'affaire est conclue dans les semaines qui suivent. L'œuvre, qui est alors une pièce unique, bien que non isolée, suscite d'emblée le débat: quelle inscription chronologique doit-on lui donner? Quelle est l'identité du sculpteur qui la façonna? Qui représentet-elle? Quelle était sa forme première: un buste? une statue en pied? trônante? Quelle était sa fonction? Pourquoi fut-elle enfouie à un moment indéterminé? Le livre, sans chercher à clore le débat, revient sur sa signification en tant que "pièce majeure de l'archéologie des sociétés de la Méditerranée antique»(p.6). Mais il s'intéresse surtout à sa trajectoire tout à fait originale lors de sa deuxième vie, celle qui débute en I897. C'est le « destin singulier » qu'évoque explicitement le titre du livre. Singulier, en effet, d'abord parce que cette Dame de pierre aima les voyages. Découverte dans le Pays valencien, exposée au Louvre jusqu'en ig40, elle regagna alors l'Espagne dans le cadre d'un échange entre les gouvernements de Pétain et de Franco. Entre i94I et 1972, elle fut exposée au Prado avant de rejoindre le Museo Arqueológico Nacional où elle se trouve toujours. Elle se rendit à deux reprises à Elche dans le cadre d'expositions temporaires et, aujourd'hui encore, sa ville natale ne cesse de demander sa restitution.

Ces pérégrinations ont contribué à en faire une icône identitaire. Dès I897, la Dame 
d'Elche donne lieu à de multiples discours et représentations, parfois contradictoires, et qui coexistent les uns avec les autres. Le livre propose ainsi, dans une perspective qui est à la fois archéologique, historiographique et anthropologique, une histoire de la réception de l'œuvre à l'époque contemporaine à partir d'une approche théorique qui s'inspire du cadre hérité de l'École de Constance. Les auteurs ont toutefois privilégié l'étude des discours érudits qui ont été produits (“les modes de réception de la statue par les lettrés », p. 7) dans la mesure où ce sont eux qui construisent "l'efficacité sociale» (agency) de la statue. De là les multiples sources, de nature très variée, que cette étude mobilise: écrits savants, journaux, textes d'érudits, entretiens, iconographie (sculptures, moulages, peintures, affiches, photographies), sans oublier les fêtes et les commémorations qui mettent en scène la Dame. Les lectures de trois catégories d'acteurs sont privilégiées: celles des archéologues du tournant des $\mathrm{XIX}^{\mathrm{e}}$ et $\mathrm{xx}^{\mathrm{e}}$ siècles, celles des artistes que la Dame a inspirés, celles des idéologues régionalistes et nationalistes qui se sont emparés de ce symbole.

Le chapitre i revient sur la découverte en fournissant des éléments qui permettent de situer l'œuvre dans son contexte culturel, celui de la Protohistoire de la péninsule Ibérique, et dans le contexte archéologique dans lequel elle fut trouvée. Le chapitre 2 étudie les débats que la Dame a suscités chez les archéologues du début du $\mathrm{xx}^{\mathrm{e}}$ siècle, tout en rappelant les apports les plus récents de la recherche (confirmation de sa fonction funéraire à un moment de son histoire, de l'origine du calcaire gréseux - provenant des carrières d'El Ferriol - qui a servi à sa réalisation). Avec le chapitre 3, on quitte le terrain strictement archéologique. Les auteurs reviennent sur la réception de l'œuvre par des artistes tels que David Dellepiane ou Georges-Antoine Rochegrosse (lectures hellénisantes et orientalisantes). L'histoire des moulages de l'œuvre est aussi considérée, en particulier les tirages faits à partir de la copie du buste réalisée par Ignacio Pinazo à la demande de l'archéologue espagnol José Ramón Mélida. Le sculpteur espagnol prolonge cette expérience jusque dans l'entredeux-guerres en trouvant dans la Dame une source d'inspiration pour plusieurs de ses créations. Ces premiers chapitres, tout à fait intéressants, présentent l'intérêt de rassembler de façon commode des informations par ailleurs connues.

De notre point de vue, les deux derniers chapitres sont les plus stimulants. Le chapitre 4 analyse la récupération de la Dame d'Elche, à partir des années I920, comme symbole identitaire valencien. Celui-ci est au service d'un discours qui postule l'idée d'une continuité entre les Ibères d'hier et les Valenciens - et les Catalans dans une moindre mesured'aujourd'hui. Dans ce schéma essentialiste, la Dame d'Elche incarne le type idéal de la femme ibère, lequel préfigure celui de la Valencienne et, au-delà, de l'Espagnole moderne. Nous signalerons en particulier les pages consacrées à la comparaison des usages symboliques de la Dame d'Elche et de la Vénus d'Arles dans la construction des discours régionalistes provençal et valencien (p. 9o-II2). De la Festo Vierginenco provençale à la Dama viviente d'Elche, en passant par les Fallas valenciennes, les auteurs mettent en lumière la place capitale que tient une certaine image de la féminité au sein de deux imaginaires qui se répondent à travers des " configurations symboliques et rituelles » proches (p. Io4).

Quant au chapitre 5, il privilégie l'étude de la récupération symbolique de la Dame dans la construction de l'identité nationale espagnole, en particulier sous la dictature de Franco, et ses avatars depuis la restauration de la démocratie. Le rétablissement de la liberté d'expression et la mise en place d'un État très décentralisé dans le cadre des communautés autonomes a en effet favorisé 
la récupération de la Dame comme symbole local puissant pour la ville d'Elche/Elx. Mentionnons en particulier les pages relatives à la réélaboration du récit de la découverte du buste à l'époque du premier franquisme par Alejandro Ramos Folqués et l'ouvrier qui aurait découvert la Dame, Manuel Campello - qui ne doit pas être confondu avec le docteur Manuel Campello, propriétaire de La Alcudia en I897 (p. II7I36). Il entre en contradiction, sur plusieurs points, avec d'autres témoignages plus anciens, en particulier ceux de Pedro Ibarra qui, s'il n'assista pas à la découverte, fut l'un des premiers à voir l'œuvre et à examiner le lieu où elle fut trouvée. Le sujet n'a rien d'anecdotique puisque privilégier telle ou telle version du contexte de découverte oriente l'interprétation ultérieure relative aux raisons qui purent conduire à l'enfouissement de la Dame à l'époque ibérique et à la signification qu'elle pouvait revêtir pour les Ibères d'Elche. Ce dossier a récemment fait l'objet d'une relecture par Sonia Gutiérrez Lloret et, de façon plus approfondie, par Ana M. ${ }^{a}$ Ronda Femenia. Ces travaux ont enrichi notre connaissance des sources relatives à cette question, mais les conclusions d'Ana M. ${ }^{a}$ Ronda, en particulier, restaient prudentes. Marlène Albert-Llorca et Pierre Rouillard adoptent, de façon très convaincante, une position plus ferme face à ce récit tardif qui entre en résonnance avec les légendes mariales. Devenu récit officiel, il est imprégné des valeurs et d'un imaginaire qui sont ceux $\mathrm{du}$ national-catholicisme. Les auteurs l'affirment avec force: il faut le «récuser formellement» (p. 123). On lira ainsi des pages tout à fait stimulantes sur “les effets sociaux » (p. I35) de ce récit, sur ses conséquences "sur la valeur symbolique conférée à la Dame » (p. I36), ou encore sur le processus de "transfert de sacralité» entre la Dame d'Elche et la Vierge, sans que l'on puisse toutefois parler d'une identification entre la mère de Dieu et une sculpture qui restait (reste?) une image païenne (p. I36-I47).

Le contenu de cette belle étude, on l'aura compris, est pour nous d'un vif intérêt. Celui-ci est double. D'une part, elle offre, en langue française, ce qui est à souligner, une synthèse concise et précise sur les réceptions de la Dame d'Elche. Mais cet essai accorde aussi une place importante à des aspects moins connus de cette histoire. À ce titre, ce petit livre est bien plus qu'un simple état de l'art. Le propos est par ailleurs servi par deux belles plumes: le discours est clair, très agréable à lire. L'illustration, très riche, est au service du texte. De ce point de vue, il est regrettable que la qualité de l'impression laisse à désirer. Le rejet des notes en fin d'ouvrage, dont nous comprenons l'usage, n'en reste pas moins tout à fait incommode pour le lecteur, d'autant plus que nous ne disposons pas d'une bibliographie finale. Celle-ci aurait pourtant été utile.

Quoi qu'il en soit, les auteurs nous offrent une enquête passionnante qui est à la fois accessible et précise, ramassée et dense, toujours stimulante. L'essai de Marlène Albert-Llorca et Pierre Rouillard offre ainsi un complément utile à une autre étude récente que nous recommandons aux lecteurs d'Anabases, celle de Carmen Aranegui Gascó (La Dama de Elche. Dónde, cuándo y por qué, Madrid, Marcial Pons, 20I8).

$$
\begin{array}{r}
\text { Grégory Reimond } \\
\text { Casa de Velázquez, Université Toulouse- } \\
\text { Jean Jaurès } \\
\text { gregoryreimondig84@gmail.com }
\end{array}
$$

Antón Alvar Nuño, Historiografía de la esclavitud, Madrid, Universidad Carlos III, 20I9, 5oo p., 33 €/ ISBN 97884132/4594.

Antón Alvar Nuño nous propose Historiografía de la esclavitud, un ouvrage copieux 
de 5 oo pages sur le thème de la condition servile et de ses traitements historiographiques. Cette thématique a été soumise par le GIREA (Groupe International de Recherches sur l'Esclavage dans l'Antiquité) pour une série de raisons explicitées dans l'introduction, comme la généralisation du relativisme culturel ou l'engouement pour les libertés individuelles, par exemple, alors même que le contexte voit se multiplier des formes d'exploitation et augmenter le nombre de travailleurs pauvres. Après cette introduction convaincante sur la nécessité de réviser la thématique de l'ouvrage - bien qu'elle manque peut-être de quelques définitions de base, notamment sur ce qu'englobe dans l'ouvrage la notion d'esclavage - trois grandes parties se succèdent, comprenant respectivement huit, cinq et neuf communications en espagnol, français et italien.

La première partie est consacrée à l'esclavage antique et la pensée politique moderne. Elle comprend des contributions générales sur le couple de notions domination/servitude, sur des aspects théoriques ou la représentation globale d'une Antiquité esclavagiste (Serghidou; Montoya Rubio; Plácido), ainsi que deux contributions portant plus particulièrement sur les États-Unis et les parallèles établis entre leur système esclavagiste et les sociétés antiques (Huguet; Martínez Maza), un point épistémologique (Annequin sur les méthodologies de la comparaison; Prieto Arciniega sur les travaux précurseurs de F. Garrido) et, enfin, une incursion dans les représentations picturales liées à l'esclavage antique de l'Espagne du xix ${ }^{e}$ siècle (Duplá Ansuategui). La deuxième partie, dédiée à l'historiographie de l'esclavage au Proche-Orient et en Grèce antiques, est plus resserrée thématiquement. Les deux premières contributions concernent l'historiographie de l'esclavage au ProcheOrient (Vidal pour la Mésopotamie; Antela-Bernárdez et Zaragozà Serrano pour l'Empire perse) et les trois suivantes celle de la condition servile en Grèce (Fernández Prieto; Valdés Guía sur Sparte et Fornis sur Athènes). Enfin, la dernière partie concerne l'historiographie de l'esclavage en péninsule Ibérique pendant la protohistoire et l'époque romaine. Elle traite d'auteurs en particulier comme Pline le Jeune (Gonzales), de lieux comme les mines (Zubiaurre Ibáñez et Beltrán Ortega), d'événements comme les révoltes serviles (Desideri; Arrayás Morales et Heredia Chimeno) ou d'historiens en particulier qui ont marqué leur époque et l'analyse de la condition servile antique (Caliri; Cortadella Morral et Sierra Martin; Alvar Nuño). Le reste de la partie est consacré plus particulièrement à l'historiographie de l'esclavage en péninsule Ibérique (Hidalgo de la Vega; Crespo Mas; Sastre, Rodríguez Fernández et Currás Rejofos). L'organisation globale du volume fait sens, même si plusieurs articles auraient pu trouver leur place dans l'une ou l'autre des trois parties. On regrette enfin les problèmes formels qui perturbent parfois la lecture, en particulier dans les articles en français, ainsi que la présence d'un index, en particulier pour les noms d'auteurs ou les notions transversales, qui aurait sans doute permis une consultation plus efficace du volume.

L'ouvrage présente cependant des qualités certaines, notamment sur le traitement de la thématique de l'esclavage moderne aux États-Unis, de son traitement historiographique et de sa comparaison à l'Antiquité. Il en va de même du traitement espagnol de l'esclavage antique en péninsule Ibérique, à plusieurs reprises. Dans ces deux cas, les articles se complètent et se répondent pour donner au lecteur une vison substantielle et bien renseignée de l'état actuel des connaissances. Concernant l'Antiquité plus particulièrement, le lecteur voit au fil des contributions que la question de la condition servile est encore totalement ouverte, y compris dans des zones où la documentation est plus abondante, 
comme Athènes ou la péninsule italique. Beaucoup de débats portent effectivement sur la précision des types de dépendance ou des modes d'exploitation. L'ouvrage entier concourt à montrer que le terme d'esclavage est souvent trop englobant et qu'il masque les subtilités de situations bien plus complexes. Par ailleurs, le lecteur pourra aussi apprécier la diversité des perspectives adoptées : par le truchement d'un auteur, la mise à jour des données, les écoles (soviétique, japonaise, espagnole, marxiste, postprocessuelle...).

Si dans sa présentation du volume A. Alvar Nuño avertit le lecteur de la grande diversité des contributions proposées, il est vrai qu'on ne peut que remarquer, à l'issue de la lecture, le côté foisonnant de l'ouvrage. Les réflexions théoriques alternent avec des études de cas bien spécifiques, sur des notions comme la pauvreté ou des auteurs anciens ou modernes, qu'il est parfois peu aisé de saisir dans toute leur complexité quand on ne dispose pas d'avance des références discutées. Cependant, la plupart des contributions font le choix d'une contextualisation de leur sujet, fort utile aux néophytes. C'est donc un volume riche que nous livrent A. Alvar Nuño et ses collaborateurs où chacun pourra trouver à n'en pas douter de quoi satisfaire sa curiosité ou étayer ses connaissances sur le thème.

\section{Élodie GuILlon \\ Université Toulouse - Jean Jaurès elodie.guillon@univ-tlse2.fr}

Federica Bessone et Marco Fucecchi (éds.), The Literary Genres in the Flavian Age. Canons, Transformations, Reception, Berlin et Boston, De Gruyter, 20I7, 36r p., Iо9,95 € / ISBN 9783ıго533224.

Il volume deriva da un convegno internazionale svoltosi a Torino nel 2013 sui generi letterari nell'età dei Flavi. L’opera si compone di sedici studi in lingua inglese suddivisi in sette parti. La prima sezione è dedicata ai generi e alla storia letteraria e, in particolare, all'opera di Quintiliano. La seconda sezione tratta di enciclopedismo e oratoria con un'attenzione particolare per Plinio il Vecchio e Plinio il Giovane. La terza sezione si concentra sulla poesia epigrammatica di Marziale e sul suo rapporto con Catullo. Nella quarta sezione l'attenzione è focalizzata sulla relazione tra poesia d'occasione e generi letterari. La quinta sezione, sui modelli e sulle trasformazioni della poesia epica, tratta di Valerio Flacco e del suo rapporto con la tradizione letteraria latina e greca. La sesta sezione passa al tema della guerra e alla tensione fra generi letterari. La settima sezione riguarda la relazione tra poesia epica e altri generi letterari. Dei tre aspetti ricordati nel sottotitolo del volume, oltre al tema del canone letterario, il filone della ricezione si declina in due sensi: la ricezione in età flavia di autori precedenti e la ricezione di opere dell'età flavia in autori successivi. Il tema della tensione, invece, si trova sia all'interno dello stesso genere letterario sia tra generi diversi.

Nella prima sezione, Citroni avverte che Quintiliano non fu un classicista e non vedeva in Cicerone il modello ideale. Egli riconosceva un progresso nell'oratoria e apprezzava alcuni aspetti sia dei veteres sia dei novi. Baier individua il principio dell'imitazione, derivante dall'utilità, come il motore dello sviluppo per la cultura e la letteratura latina in un rapporto dinamico tra imitazione e innovazione in cui è fondamentale l'elemento della ricezione. Nella seconda sezione Citroni Marchetti analizza il concetto di cura nell'opera di Plinio il Vecchio e distingue il senso della cura dall'etica della cura con una contrapposizione tra l'etica materna e quella guerresca. Balbo studia il legame tra gli oratori di età flavia e il potere con due esempi tratti da Plinio il Giovane. Lo 
studioso mette in evidenza la necessità di equilibrio e prudenza in campo politico, ma anche le posizioni antitiranniche e il tema della libertas.

Nella terza sezione, Canobbio studia la gerarchia dei generi letterari in Marziale che, con la ripresa del tema della recusatio, si oppone ai generi maggiori. In Stazio, invece, si riscontra una contaminazione tra diverse forme poetiche in cui sono importanti il tema della varietas e l'influenza del pubblico. Morelli studia i legami intertestuali tra Marziale e il carme 23 di Catullo e sottolinea immagini, termini e suggestioni che il poeta flavio deriva dal poeta neoterico. Nella quarta sezione, Merli approfondisce il concetto difestinatio nella poesia romana. Questo termine è caratteristico della poesia professionale e non si pone in contrasto al labor limae. Bonadeo studia la costruzione di un canone letterario minore tra Stazio e Marziale che è modellato su quello degli autori maggiori (Omero e Virgilio). Newlands si occupa della ricezione delle Silvae di Stazio in Sidonio Apollinare e, in particolare, analizza il carme 22 di Sidonio. Nel poeta tardoantico si ritrova la volontà di conservare la tradizione culturale e l'intenzione di innovare il genere letterario.

Nella quinta sezione, Fabre-Serris si occupa dell'interpretazione del mito argonautico in Valerio Flacco ed evidenzia le differenze rispetto a Catullo, Seneca e Apollonio. Valerio Flacco rinuncia all'interpretazione moralistica del mito; il viaggio degli Argonauti rappresenta così l'inizio della storia per l'umanità. Zissos sottolinea le differenze di Valerio Flacco rispetto ad Apollonio Rodio in relazione alla figura di Ipsipile e al mantello da lei donato a Giasone. Questo episodio diventa un esempio di pietà filiale e di progetto matrimoniale in cui è forte l'influenza del modello virgiliano.

Nella sesta sezione Lovatt tratta il tema della guerra in Stazio attraverso il confronto gli autori precedenti e coevi. In
Stazio la guerra assume un tono oscuro per l'influenza di Lucano. Littlewood analizza la sezione centrale dei Punica di Silio Italico e sottolinea l'instabilità del genere letterario, a cavallo tra elegia erotica e mondo tragico. Lo studioso si concentra sul tema del fato degli uomini che è manipolato dagli dei, su quello del conflitto interno e sulla costruzione del personaggio di Annibale. Marks approfondisce il ritratto di Grosfo - alleato dei Romani ad Agrigento - in Silio Italico e mostra come il poeta abbia proceduto all'epicizzazione di Callimaco, Orazio e Ovidio. Emerge anche una relazione mimetica tra la poesia epica di Silio e l'azione militare di Roma. Il saggio si distingue per la raffinatezza nell'uso degli strumenti intertestuali, la chiarezza espositiva e l'efficacia argomentativa. Keith chiude la sezione con il programma poetico e la rappresentazione di Achille nell'Achilleide di Stazio. L'eroe si presenta come cantore e maestro della lirica e con la figura dell'eroe il poeta allude alla propria contemporanea produzione poetica delle Silvae.

Nella settima sezione Augoustakis studia i riti funebri in Silio Italico e la relazione tra il poeta e le sue fonti. Il rito funebre acquista una dimensione simbolica a cui si accosta una rappresentazione in chiaroscuro di Annibale: emerge così l'umanità del cartaginese ed è prefigurata la sua sconfitta finale. Nell'ultimo studio Reitz presenta la figura di Capaneo nella Tebaide di Stazio come un eroe epicureo che viene punito secondo le dottrine della poesia didascalica; emerge così la superiorità dell'epica sulla tragedia e sull'epica didascalica.

Il merito principale del volume è il fatto di offrire uno sguardo ampio e approfondito sulla letteratura dell'età dei flavi anche se ciò comporta qualche squilibrio tra le varie sezioni. L'elemento unificante è costituito dalla riflessione sul tema dei generi letterari che tuttavia non si ritrova in modo omogeneo in tutti gli studi. Proprio la fluidità e le tensioni tra generi, 
caratteristiche dell'epoca analizzata, costituiscono un ottimo banco di prova per verificare la tenuta concettuale e l'utilità critica della nozione di genere letterario.

Amedeo Alessandro Raschieri Università degli Studi di Milano amedeo.raschieri@gmail.com

Marco Buonocore (éd.), Corpus inscriptionum Latinarum. Inscriptiones Calabriae Apuliae Samnii Sabinorum PiceniLatinae. Supplementum. Regio Italiae quarta. Vol. IX. Suppl. Pars I. Fasc. I, Berlin, De Gruyter, 2018, 418 p., $239 € /$ ISBN 9783ıго62796I.

Marco Buonocore (éd.), Corpus inscriptionum Latinarum. Inscriptiones Calabriae Apuliae Samnii Sabinorum PiceniLatinae. Supplementum. Regio Italiae quarta. Vol. IX. Suppl. Pars I. Fasc. 2, Berlin, De Gruyter, 2019, 446 p., $239 € /$ ISBN 9783ıго67г643.

MarcoBuonocore(henceforthB.) recounts the story of this project in the preface to the first volume of his Supplementum to CIL IX. He first came up with the idea during a train journey (LXXIII: cum pulcherrimas regionis Aprotinae plagas... e hamaxostichi fenestra contemplatus essem) from Chieti to Rome on I2 September 1979: having worked for some time on the inscriptions from Teate Marrucinorum, he realised the need for a systematic reconsideration of the epigraphy of the Augustan regio $I V$. Four decades on, the first two instalments of the five-volume project have been published under the auspices of the Berlin-Brandenburgische Akademie der Wissenschaften, where the CIL has been based since its inception; the whole series should be published by 2022. What has appeared so far would already be enough in itself to bring meaning and distinction to a lifetime's work: nearly I,ooo pages, 8I4 new inscriptions from 27 communities, and new readings and notes for hundreds of texts already included in CIL IX. Yet this is very much the crowning achievement of a scholarly career in which B. has set new standards to the study of Roman Italy with a major set of contributions to the ancient history and epigraphy of Central Italy (mostly collected in L'Abruzzo e il Molise in età romana tra storia ed epigrafia, L'Aquila 2002), has led to successful completion a major project on the letters of Theodor Mommsen to his Italian correspondents (reviewed in Anabases 28, 20I8, p. 3oI-3o6), and has of course had a distinguished term of service as Scriptor Latinus and Director of the Archives of the Vatican Library. It is hard to escape a sense of deep admiration and gratitude for a contribution to the understanding of ancient Italy that has few equals in the last century.

A detailed assessment of such a rich and complex work would easily exceed the confines of a book review, and would probably be pointless. Like all great reference collections, this is first and foremost a working tool, which must be put to the test of frequent and extensive consultation, and will be a springboard for future research in ways that are now largely impossible to predict. Moreover, this is not a work that provides any synthetic overview. Unlike the two major corpora in whose tradition it belongs - the CIL and the Supplementa Italica - it does not provide any general introduction to the history, topography, and epigraphy of the communities whose material it discusses, but takes its readers in medias res. For each community there is a list of addenda et corrigenda to the entries in CIL IX, followed by the edition of new inscriptions (tituli novi); there are plenty of cross-references, but no summative discussions. That does not remove the fact that each entry rests on and reflects a comprehensive knowledge of 
the wider picture; it is, however, an outcome of the rules of engagement that B. has set himself, and readers will do well to bear it in mind as they approach this work.

What may be more usefully be done here is a discussion of the main aspects of what this edition has to offer. For each new text included in the discussion B. provides three crucial sets of information: an account of the archaeological context; an edition; and a strikingly comprehensive bibliography. For the texts that are already included in CIL IX a full new edition is given only in a minority of cases, and the main problems that require attention are discussed in the commentary. Onomastics receives especially careful consideration throughout, and the notes helpfully refer to the contributions on individual names. We are not looking at a new Schulze, but the significance of the information gathered by B. marks a considerable step beyond anything we had at our disposal to date. A similar approach applies to epigraphical formulae: readers are consistently directed to one or more scholarly treatments, which will in turn provide further comparanda and contextual information.

Whenever he has been able to locate an inscription, B. has inspected it, and has given measurements and paleographic information, which is so often crucial to a tentative dating; he has also printed a considerable number of images. The whole work is in Latin: B. writes in an elegant and precise fashion, and stays clear of polemics; errores sprevi is probably the harshest criticism he will have in store for his predecessors, and only with the specific intention of justifying his own editorial choices. We are presented with a resource that surely only B. would have been able to produce, and one can tell the gusto with which he has been working on this material; yet his editorial voice never stands in the way of the efficient use of this work. Its offerings are incredibly generous, and users of this collection should be prepared to the real possibility of being surprised every step of the way. At any rate, no serious work on Central and Southern Italy will now be possible without making systematic use of this edition.

The first section of the work is devoted to the Samnite communities of the regio $I V$. We are presented with a splendid set of material from Telesia (p. 849-9o3), which provides essential foundations for the history of the city's magistracies (especially its praetores duouiri) and for its position in the late Republican period: B. does not provide a firm view on Mommsen's theory that regarded it as a Sullan colony, but provides all the necessary tools for a reconsideration of the problem. The edition of the evidence from Allifae (p. go395o) required extensive use of epigraphic manuscripts; a craft in which B. is an established master. Some of the inscriptions included in this Supplement are classic pièces de résistance of the epigraphy of Roman Italy, and B. provides wonderfully thorough summaries of the scholarship on documents of major importance like the Saepinum edict on transhumance (CIL 9.2438) and the law on the temple of Jupiter Liber from Furfo (9.35ı3); in those instances, and in a few carefully selected others, he also provides a working Italian translation, briefly deflecting from his main linguistic choice. Some of the material from Fagifulae (e.g. 2573,2623 ) is claimed back from the neighbouring territories of Bovianum Undecimanorum and Terventum to reflect the advancements in our understanding of the boundaries of those communities - a front of investigation that remains especially fruitful for this part of Italy.

The second part is devoted to the Frentani: Iuvanum has yielded mostly funerary material, but there are interesting dedications by the local seuiri and some honorary inscriptions. The third one, on the Marrucini, is opened by Teate, where B.'s interest in the epigraphy os this region was first kindled (the funerary dedication to 
L. Poditius by his mother Aufidia Minata, no. $7 \mathrm{OI} 7$, is a piece of arresting beauty; and those who look for an illustration of B.'s working method in this edition will find a crisp and very effective example here). The fourth section is devoted to the Paeligni. The edition of no. 7086, a long and remarkable funerary inscription found at Torre dei Passeri, is especially rewarding. The most substantial dossiers, at least in quantitative terms, are those of Sulmo and Corfinium, where the evidence for the priestesses of Ceres receives a valuable reconsideration that historians of Italic religion will consult with profit. Superaequum presents a sizeable set of documents from the Christian cemetery, to which B. devotes especially close attention, building on the work of Father Antonio Ferrua.

The fifth section, on the Vestini, focuses the attention on smaller communities, in which the pagus structures play a more prominent role: Aternum, Angulus, Pinna (with the remarkable offer to Iupiter Victor from four magistri fani, no. 7454: a document that would deserve a freestanding study; and the two funerary monuments set up by families of freedmen, with their proud portraits, no. 7476 and 748I), Furfo, Pagus Fificulanus. An inscription from neighbouring Aufinum is known thanks to the testimony of Ranuccio Bianchi Bandinelli, who wrote about it in a letter to Valerio Cianfarani: B. publishes the drawing he located in the Bianchi Bandinelli Archive in Siena (no. 75r5). The ample deployment of illustrations enables readers to weigh up the significance of the many funerary inscriptions presented here: in the large set of material from Peltuinum, for instance, the monument for the slave Onesimus (no. 7566) deserves special attention, and not just for the carmen that is inscribed on it. The inscriptions of Aveia include both attestations of the time-honoured cult of Feronia, who had her own collegium there (3602, 7624), and of the presence of the cult of Mithras $(3608,7622)$.
As even this most cursory and inadequate survey shows, we are looking at a body of material and scholarship that will significantly change the way we go about studying and teaching Roman Italy. It is a work in two large volumes, written in Latin, published in hard copy only, and for which no bespoke external funding was ever secured: it is candidly unzeitgemä $\beta$. And yet it is hard to think of a more timely, inspiring, and lasting contribution to our knowledge and debate.

Federico Santangelo

Newcastle University federico.santangelo@ncl.ac.uk

\begin{abstract}
Marco Cavalieri, Olivier Latteur (dir.), Antiquitates et Lumières. Étude et réception de l'Antiquité romaine au Siècle des Lumières, Louvain, Presses universitaires de Louvain, 2019, 342 p., 29,5o €/ ISBN 978287558824I.
\end{abstract}

Après une courte préface de G. Montègre portant sur la place de l'Antiquité dans les débats et réflexions du Siècle des Lumières, M. Cavalieri et O. Latteur introduisent cet ouvrage qui fait suite au colloque de Louvain-la-Neuve du 6 octobre 2017. L'objectif est d'illustrer les différentes tendances intellectuelles visibles chez les antiquaires des Lumières en interrogeant leur interprétation et réappropriation de l'Antiquité romaine et plus globalement leur rapport au passé comme à leur époque. L'ouvrage est construit suivant cinq axes.

Le premier porte sur la relecture et l'édition des sources anciennes au Siècle des Lumières. I. G. Mastrorosa s'intéresse à la méthode de Louis de Beaufort, un des premiers érudits à pointer le manque de fiabilité de l'histoire romaine. L'auteure montre que l'historiographe questionne la tradition littéraire par l'analyse d'invraisemblances et omissions, conjecturant que 
ces écrits servent en partie les propagandes familiales. E. Famerie présente ensuite différents traducteurs français des Lumières et interroge leurs motivations à traduire Végèce et son abrégé d'art militaire. Il identifie d'abord le désir de mieux comprendre l'art militaire romain, puis celui de mettre en pratique ses enseignements.

La deuxième partie traite du rapport entre le pouvoir officiel et les réseaux intellectuels d'académies et d'antiquaires. Ch. Grell revient ainsi sur les conséquences des découvertes vésuviennes sur les intellectuels européens. Elle identifie ainsi trois périodes allant des premières fouilles très protégées aux premières publications et controverses autour des vestiges archéologiques, et jusqu'à l'arrivée du Vésuve et de ses éruptions comme nouveau sujet de préoccupation. M. Cavalieri met en évidence le même intérêt du Duché de Parme pour les découvertes, notamment de Veleia, mais montre qu'au-delà des enjeux culturels et esthétiques, ces dernières sont avant tout utilisées par l'État pour mettre en valeur son prestige. L'excellence de la recherche, la stratégie de publication et les fondations institutionnelles servent surtout les intérêts de la monarchie. O. Latteur concentre son étude sur l'ouvrage de PierreJoseph Heylen à propos des monuments archéologiques romains de Belgique. À travers une analyse structurelle de cette dissertatio, il révèle le contexte intellectuel de l'époque et le fonctionnement des réseaux intellectuels et institutionnels.

Un troisième volet offre différents exemples de travaux d'antiquaires locaux. V. Krings et B. Pilot abordent cette thématique sous l'angle de la correspondance autour de Jean-François Séguier et Anne-Marie d'Aignan d'Orbessan. Après avoir dressé leurs biographies respectives, ils interrogent l'origine et les mécanismes liés à leur intérêt pour l'Antiquité qui diffère, sur le plan du référencement des antiquités comme dans leurs relations aux réseaux de l'époque. H. González Bordas propose une étude des productions de Francisco Ximenez portant sur l'épigraphie latine d'Afrique. Il relève chez l'antiquaire des caractéristiques et méthodes spécifiques, notamment l'esprit de collaboration et le souci d'exhaustivité, à l'écart des cercles de l'époque. V. Beirnaert-Mary présente enfin le cas de Jean-Baptiste Lambiez autour de Bagacum Nerviorum. Revenant sur sa formation et ses méthodes, elle présente notamment ses publications et ses fouilles, et notamment son ambition de protection et de conservation vis-à-vis des antiquités qu'il rencontre.

Un quatrième axe aborde la réception spécifique des cultes isiaques à travers deux articles. Le premier, offert par A. Guédon, analyse la présence des trouvailles isiaques impériales dans le Recueil d'Antiquités du comte de Caylus. L'intérêt de l'antiquaire pour la plasticité de la religion romaine transparaît à travers l'analyse de la gens isiaca. La démarche du comte apparaît comme novatrice: les identifications sont issues d'une comparaison de différents types de sources et le lien entre culte et pouvoir est évoqué malgré une vision essentialiste et morale de la civilisation romaine. C. Trouchaud, à partir d'un article de 1957 et après avoir présenté la terminologie ancienne, remonte la piste historiographique du terme d'horus lock et identifie l'origine de ce terme dans la relation entre les antiquaires Charles Townley et le Baron d'Hancarville qui, grâce à leur influence et leur autorité, ont permis la diffusion de ce néologisme à travers leurs écrits.

La dernière partie s'intéresse aux collections d'antiquités et à leur mise en scène. Ce sont d'abord les monnaies qui sont abordées avec la contribution de Fr. de Callataÿ. L'auteur questionne les causes du déclin de la numismatique $\mathrm{au} \mathrm{XVIII}^{\mathrm{e}}$ siècle à travers une vaste étude des correspondances et des réseaux. Il identifie ainsi des facteurs intellectuels, esthétiques mais aussi économiques. 
$\mathrm{S}$. Andrès aborde ensuite les portraits à l'intérieur du salon du connaisseur, imitation du salon aristocratique. Souvent décontextualisés, l'identification de ces portraits repose sur la lecture des sources littéraires et dans une moindre mesure sur la comparaison : sont recherchés avant tout la rareté, l'exhaustivité et le goût pour l'Antique. K. Michini analyse la présence de l'Antiquité dans les jardins à l'anglaise en Italie et leur influence intellectuelle. Grâce à l'exemple des jardins des frères Picenardi à Crémone, elle montre les enjeux de la construction, de mise en valeur des vestiges antiques et notamment des collections lapidaires ainsi que leur portée dans les réseaux européens.

O. Parsis-Barubé conclut le volume par une réflexion méthodologique, rappelant le tiraillement de l'histoire des antiquaires entre pratique savante et prédation des vestiges. Le $\mathrm{xvII}^{\mathrm{e}}$ siècle montre une triple évolution: le rapprochement de la figure de l'érudit de celle de l'historien, le développement d'un intérêt pour les vestiges locaux et nationaux en même temps qu'une recherche géographiquement variée, et un intérêt accru pour l'objet et non plus seulement pour la littérature. L'ensemble de l'étude contribue aux réflexions sur la théorie de la réception en interrogeant tout autant les schémas de pensées, les modalités que les usages liés à l'Antiquité.

L'ouvrage atteint son objectif: sur un sujet qui pourrait sembler convenu, il démontre, par la richesse des approches, sa pertinence. L'étude de la réception de l'Antiquité met en lumière des mécanismes propres au Siècle des Lumières, rejoignant ainsi les préoccupations de l'histoire intellectuelle et esthétique, de l'histoire des réseaux comme de l'histoire économique et politique. Loin d'épuiser la thématique, il la renouvelle et ouvre la voie à d'autres études.

Arnaud SAura-ZiEgelmeyer Université Toulouse - Jean Jaurès a.sauraziegelmeyer@gmail.com
Jean-Michel David, Frédéric HurLet et Martin Jehne (dir.), “ La culture politique de la République romaine. Die politische Kultur der römischen Republik », dans Trivium, 3I, 2020 (revue en ligne : https:// doi.org/I0.400o/trivium.697I).

C'est un fait bien connu que le plurilinguisme en vigueur en histoire ancienne constitue une richesse, mais aussi un frein à la connaissance des travaux de l'historiographie étrangère. C'est particulièrement vrai des travaux publiés dans la langue de Goethe. C'est cet obstacle que s'efforce de lever ce numéro de la revue Trivium, revue en ligne franco-allemande publiant des traductions d'articles de sciences humaines, consacré à la culture politique de la République romaine. Naturellement un tel dossier se place sous les auspices de C. Nicolet et de C. Meier qui furent les pionniers de ces études en France et en Allemagne. Or ces deux “pères-fondateurs » ne collaborèrent pas ensemble et si C. Nicolet s'est intéressé aux travaux de C. Meier, la réciproque n'est pas vraie. Ce sont leurs héritiers, au premier rang desquels J.-M. David, M. Jehne et H. Bruhns, qui, depuis une trentaine d'années, s'efforcent de favoriser le dialogue entre les historiens français et allemands. Cette entreprise est une nouvelle occasion d'y encourager en proposant un bilan de plus d'un demi-siècle de recherches et en faisant (re)découvrir des textes essentiels ayant renouvelé notre conception du politique à Rome.

Le dossier s'ouvre sur une présentation par J.-M. David des deux modèles interprétatifs de la République romaine, allemand et français, nés dans les années ı96o sous la plume de C. Meier et de C. Nicolet. Bien que les deux suivissent une démarche structurale, ils divergeaient quant à leur approche : C. Meier s'attachait à la crise de l'aristocratie romaine à l'origine de l'effondrement de la République à travers les mutations de la grammaire 
politique, tandis que C. Nicolet examinait le «métier de citoyen ». L'un restait dans la tradition allemande d'histoire juridique et politique s'appuyant sur la sociologie et l'autre s'inscrivait dans la filiation des Annales en conservant un intérêt pour les questions sociales et économiques. Ces deux modèles, qui s'ignorèrent tout d'abord, eurent une grande postérité, et ce sont donc leurs élèves qui font le bilan de plusieurs décennies de recherche.

J.-M. David et F. Hurlet offrent un tour d'horizon exhaustif de l'historiographie française de la République romaine depuis I96o. Naturellement la figure de C. Nicolet y occupe une place centrale parce que nombreux furent ses élèves et ceux qui suivirent son exemple. Toutefois l'article commence par souligner la diversité des recherches en rappelant les progrès de l'histoire économique avec J. Andreau, le renouveau del'histoire religieuse influencée par l'école de Paris avec J. Scheid, ou la portée des travaux de romanistes comme A. Magdelain, M. Humbert et Y. Thomas. Vient seulement ensuite la présentation du “moment Nicolet» puis de “l'École fondée par Nicolet » qui offre une synthèse des travaux de la majorité des historiens français de la République romaine depuis une cinquantaine d'années, signe de l'influence profonde qu'exerça C. Nicolet. Le renouvellement générationnel et thématique est enfin abordé pour souligner la pertinence toujours actuelle du concept de culture politique qui va de pair avec la continuité du recours aux sciences sociales. Une remarque intéressante porte sur la particularité française de l'association de l'histoire et de la géographie dans les cursus universitaires dont découle la sensibilité aux questions spatiales.

M. Jehne répond par une présentation de l'historiographie allemande sur la République romaine, citant moins d'auteurs mais détaillant davantage leurs travaux. Cette fois, c'est bien sûr C. Meier qui occupe le devant de la scène, plus particulièrement la rupture opérée par son opus magnum et par son concept de " crise sans alternative ». Contrairement à C. Nicolet, C. Meier ne fit pas école mais eut néanmoins des élèves qui prolongèrent ses travaux dans des domaines variés : sur la crise $(H$. Bruhns et K. Raaflaub), l'ordre public (W. Nippel), les élections (R. Rilinger), ou l'émergence de la nobilitas (K.-J.Hölkeskamp). Sont ensuite abordés l'essor de l'anthropologie historique, les changements de l'histoire économique et sociale, l'histoire du droit où se distingua J. Bleicken, et la réception des ouvrages de C. Nicolet et de P. Veyne en Allemagne. Ce sont en réalité les travaux de F. Millar sur la nature du régime républicain qui rassemblèrent les historiens allemands dans une opposition à l'idée d'une démocratie à Rome. Ce débat favorisa la poursuite des travaux sur la culture politique, comme ceux d'E. Flaig autour du consensus ou d'H. Mouritsen sur les contiones.

De tels panoramas, nécessairement allusifs, ont toutefois le double mérite de signaler les travaux de la rive du Rhin dont on est le moins familier et de les mettre en perspective. Ils visent ainsi avant tout à favoriser le dialogue en éliminant la barrière de la langue et en faisant connaître les avancées marquantes. C'est le même objectif que suit le reste du dossier composé de traductions en français d'articles de M. Jehne, de K.-J. Hölkeskamp, d'U. Walter puis de celle en allemand d'articles de J.-M. David, de F. Hurlet, de M. BonnefondCoudry et de J.P. Guilhembet. Les deux figures tutélaires, C. Meier et C. Nicolet, inaugurent chaque section avec la traduction de la préface de leur livre classique : Res publica amissa et Le métier de citoyen.

S’il n'est pas nécessaire de revenir sur ces travaux bien connus, nous pouvons dire un mot de leur choix. Tous mobilisent bien sûr le concept de culture politique : en le présentant pour s'opposer aux théories de F. Millar (K.-J. Hölkeskamp); pour explorer l'inscription des manifestations 
de violence collective (J.-M. David) ou des appels au passé (U. Walter) dans la grammaire politique; pour montrer la continuité de la concurrence, typique de la République, sous le Principat (F.Hurlet). Ils sont aussi représentatifs des différentes écoles historiques. Ainsi les articles de M. Bonnefond-Coudry et de J.-P. Guilhembet illustrent l'attention aux questions topographiques caractéristique de l'école française tandis que celui de M. Jehne témoigne de l'intérêt porté aux formes de communications entre les élites et le peuple par l'historiographie allemande.

Ce numéro de Trivium constitue donc un nouvel appel bienvenu au dialogue entre historiens français et allemands et une initiative salutaire pour préserver le multilinguisme, essentiel pour la finesse et la diversité de la réflexion. L'intérêt d'une telle démarche ne peut que sauter aux yeux à la lecture du dossier que nous recommandons à tous les historiens de Rome.

Clément Bur Institut National Universitaire Champollion (Albi) clement.bur@univ-jfc.fr

\begin{abstract}
Stephen L. Dyson, Archaeology, ideology and urbanism in Rome from the grand tour to Berlusconi, Cambridge et New York, Cambridge University Press, 2019, 327 p., \$ 105 / ISBN 9780521874595.
\end{abstract}

Research in the history of archaeology, its connections with political authority and its role in shaping identities and cultural memory has been blossoming for more than two decades now; yet the possible topics and angles for further research are far from being exhausted. The author of this monograph is not new to this kind of studies, as he is the author, among other publications, of Ancient
Marbles to American Shores. Classical Archaeology in the United States (1998) and of In Pursuit of Ancient Pasts: A History of Classical Archaeologyin the Nineteenth and Twentieth Centuries (2006). Dyson has also published in 2003 a volume on the studies on the Roman countryside (The Roman Countryside) which seems to represent a sort of mirror to this new book on the city of Rome.

The history of Italian archaeology, and of Italian Classics in general, has been thoroughly studied in the country, with a very critical eye, starting with the collective volume Matrici culturali del fascismo (1977, absent in Dyson's bibliography). In this sense, the author of this monograph makes through this volume many most important results of such Italian research available for a wider readership who may not be able to gain direct access the Italian-language works of scholars such as Marcello Barbanera (as for example his seminal L'archeologia degli italiani, 1998) or Daniele Manacorda.

Yet it is particularly surprising that the contributions to the topic by Mariella Cagnetta, in the mentioned collective volume of 1977 and elsewhere, are missing from the bibliography.

The present study proceeds chronologically through its eleven chapters: after a short introduction, the author begins with the Enlightenment, and more precisely with "Rome in the Eighteenth Century" (p.8-32), to investigate then the revolutionary period and Napoleonic domination (p.33-56), the last decades of the Papal States (p. 8I-Ioo). The book then follows the new ideological and practical challenges set to Rome and its archaeological heritage by the new role as capital of the Kingdom of Italy (p. IOI-I28), with a special focus on museums, displays and the antiquities market, dealt with in a separate chapter (p. I29-I53). The next two chapters are dedicated to the Fascist period, "Archaeology and Urbanism in 
Fascist Rome" (p. 154-I79) and "Mostras and Museums in Fascist Rome" (p. I8o202). The final section of the book looks at the second half of the $2 \mathrm{O}^{\text {th }}$ century and the very beginning of the $2 \mathrm{I}^{\text {st }}$ : after dealing with the I95os and ig6os and their challenges (p. 203-235), the author focuses on the 'new' approach to archaeology starting in the I970s, which he pinpoints to the biography of individual archaeologists as Adriano La Regina, Eugenio La Rocca or Andrea Carandini (p. 236-258). The final chapter (p. 259-286) is dedicated to the preparations for the Jubilee of 2000 and the debates that surrounded (and still surround) the new Ara Pacis museum, inaugurated 2006.

The author seems to have stopped research for this volume in 2013 - this is the year of the most recent publications in the bibliography, with the sole exception of Posner's God's Bankers (2015). For a book published in 2019, this is a long gap - and indeed the author would have profited much from reading, among others, Antonino De Francesco's The Antiquity of the Italian Nation (2013), Aristotile Kallis' The Third Rome, I922-I943: The Making of the Fascist Capital (2014; actually, none of Kallis' publications are present in the bibliography - even if the author has been working for many years on the cult of the 'Romanità' in fascist Italy), Marcello Barbanera's Storia dell'archeologia classica in Italia (2015), many contributions in Helen Roche's and Kyriakos Demetriou's Brill's Companion to the Classics, Fascist Italy and Nazi Germany (20I7), further journal articles that have appeared in the past six years.

On a general level, the volume begs the question, who is the ideal reader, for whom it has been written. Specialists and scholars of Classics, Classical archaeology and Classical receptions may find it a useful summary and a possible work of reference for specific personalities and initiatives; but scholars of modern and contemporary history will not find much new. On the other hand, a broader interested public will find the structure of the book extremely hard to follow. The decision to follow a strictly chronological structure seems at many points to be unfortunate, as it compels the author to numerous repetitions, to anticipate often something that will be explained later, and break down complex histories, dealt with in different chapters. The general reader will therefore find almost no orientation in Roman topography, as interventions in different parts of the city are juxtaposed following chronology (not to mention the fact that even the chronological structure is sometimes lacking a clear order, see e.g. p. 92-94). Another example is that of the Collezione Torlonia, which reappears at different stages (p. I36-I37; 239-240; 286), while a systematic treatment of its history would have been easier to follow and much more meaningful. Students of Classics (and maybe occasionally a scholar, too) will also be at a loss, as the historical frame of the $18^{\text {th }}$ to $2 \mathrm{I}^{\text {st }}$ century is barely explained - the year I86I and the proclamation of the Kingdom of Italy, for instance, are not mentioned anywhere, and it is expected that the reader already has a basic knowledge in the history of modern Italy.

This lack of contextualization expands into a relevant weakness: the author does not deem necessary to consider the entanglement of archaeological research with education and higher education. Beyond the anecdotic reference to one or the other protagonist being a professor, there is little reflection on structures and the ways they condition archaeological research. In the end, the entire book relies more on narrative than analysis. It is a pity, for instance, that the stories about the creation of the various Roman museums are never put into their historical context - the birth of the national museums, their function for purposes of nation building, the birth and development of nations and nationalisms, etc. The role of diplomacy, of embassies and delegations in the development of interest in Classical Antiquity and in the birth of 
the foreign archaeological schools in Rome are also insufficiently dealt with - the lack of attention given to a protagonist of this scene is exemplified in the description of Christian von Bunsen as merely "der gelehrte Diplomat" (on Bunsen, see F. Carlà-Uhink - S. Giorcelli Bersani, Monsieur le Professeur... Correspondances italiennes, I853-I888. Theodor Mommsen, Carlo, Domenico, Vincenzo Promis, Paris 20I8, p. 70-8o).

Yet, on the other side, political institutions are presented and discussed in their 'interferences' with archaeology. While the author argues that the inauguration of the new Ara Pacis museum is a good episode to close the volume (what happened later is mentioned briefly, but it does indeed probably represent a too recent history to be correctly assessed), the reader gets a strong impression that the author wanted to close on a pessimistic note, revealing strong doubts and fears about the future of Roman archaeology (the Ara Pacis is thus "the last creation of a dynamic archaeological era which was about to pass", p. 286). This tone comes across strongly throughout the book, except for a few moments when the author discusses archaeological figures whom he finds congenial. Despite the frequent assertions that Rome was no different from other European or American cities, and that the challenges posed by the Urbs are incomparable to those posed by other modern metropoles, the volume develops throughout a sort of 'paternalistic' stance that seems to imply that Italian states and governments could never have been able to take care of their cultural heritage were it not for a few 'illuminated' colleagues, whose merits and achievements are frequently represented in the book as a sort of one-man-campaign against the institutions. The "One-man-campaign" narrative foregrounds a pronounced gender bias of the book - women are conspicuously absent, even in the last chapters, dealing with a time in which many were active in Italian archaeological scholarship. Margherita Guarducci is mentioned only once (p. 205), in reference to the Vatican excavations; she is curiously portrayed as "a highly respected scholar, but also a devout Roman Catholic", without any reference to her tenure as the chair of Greek Epigraphy and Antiquities from 193i to 1973, or to her other institutional roles; Clementina Panella is never mentioned: her excavations at the Arch of Constantine, which led to the discovery of the Meta Sudans, are anonymized as "provocative" excavations (p. 252).

The lack of attention and care for institutions and structures generates sometimes glaring mistakes: for example, when the author does not seem to distinguish between regions and provinces, two very different administrative units in Republican Italy (p. 275). In general, the book shows a surprising lack of care - also and especially of editorial care. Typos and mistakes abound throughout the volume. Some of them are particularly jarring, and most notably the fact that throughout the entire book Antonio Muñoz has become Antonio Mũnoz. Almost every sentence quoted in Italian is wrong, sometimes in ways beyond comprehension (the name Vittorio Emanuele, for instance, in English Victor Emmanuel, becomes Victor Emmanuele, or even Vittore Emmanuele!). For an author who stresses, among the strengths of the archaeologists he particularly likes, such as La Regina or Carandini, that they know English, adding that this is 'unusual' among their colleagues, this complete lack of attention for the Italian language smells again of anglophone 'paternalism'.

Filippo CARLÀ-UHINK Universität Potsdam filippo.carla-uhink@uni-potsdam.de 
Alexandra Eckert et Alexander Thein (éds.), Sulla. Politics and Reception, Berlin et Boston, De Gruyter, 2019, 207 p., 79,95€ / ISBN 9783ıго6ı8099.

Tyran sanguinaire, fossoyeur de la République, réformateur... Sylla fait partie de ces personnages ambivalents à la postérité contrastée. L'ouvrage propose de revenir sur l'homme et ses actes dans une perspective diachronique. Ainsi une place est-elle faite à l'époque de Sylla, mais aussi à l'héritage du dictateur dans la vie politique, puisque son ombre continue de planer pendant des décennies, et plus largement à la construction mémorielle dans les sources gréco-latines. Sulla. Politics and Reception est la publication des actes d'une rencontre scientifique ayant eu lieu du 22 au 25 juin 20 or à l'University College de Dublin. Neuf études de cas sont réparties dans deux parties, l'une plutôt consacrée à l'approche politique et contemporaine, tandis que l'autre s'intéresse à la réception. L'introduction d'A. Eckert et A. Thein s'attache d'abord à retracer les grandes caractéristiques de la vie et de la carrière de Sylla avant de s'intéresser à sa réception ancienne et moderne, en la replaçant dans une perspective historiographique. Quelques aspects sont privilégiés, comme lafelicitas et l'exemplum négatif.

La première partie "Politics» débute avec la contribution de C. Steel (« Sulla the Orator ») qui analyse chronologiquement l'éloquence du patricien. Son art oratoire s'inscrit d'abord dans un contexte militaire (la guerre contre Jugurtha) avant de valoriser ses réformes et montrer comment la res publica devait fonctionner. Absent du Brutus de Cicéron, Sylla n'aurait pas utilisé l'éloquence comme un atout de persuasion dans un contexte électoral. Si les sources littéraires étaient au cœur du premier article, celui de S. Zoumbaki («Sulla's Relations with the Poleis of Central and Southern Greece in a Period of Transitions ») met plutôt l'accent sur l'épigraphie et la numismatique pour illustrer les conséquences de la première guerre mithridatique considérées comme un revitalising shock (p. 52). C'est une rupture pour les poleis qui doivent s'adapter à des formes plus dures de l'impérialisme romain, économiquement et socialement (pillages des métaux, confiscations de terres...). Pourtant, l'épisode syllanien semble avoir mis fin à une période de stagnation, en ouvrant une phase de transition.

Les trois contributions suivantes abordent les limites des pouvoirs syllaniens. C. Rosillo-López (“ Can a Dictator reform an Electoral System? A Reassessment of Sulla's Power over Institutions ») s'intéresse aux relations entretenues par Sylla avec le peuple et aux conséquences des réformes sur les mécanismes et pratiques électorales, comme le choix de ne pas abolir le vote secret. L'influence syllanienne est aussi minimisée, puisque ses partisans n'étaient pas forcément élus. La mise en lumière des difficultés syllaniennes permet de conclure qu'il ne fut pas a new Servius Tullius (p. 67). Ensuite, A. Thein (“Dolabella's Naval Command ») s'intéresse à la volonté de Sylla d'ôter un commandement à Cn. Cornelius Dolabella, soit le consul ou le préteur homonyme de 8I (Plut., Comp. Lys. Sull., 2, 4). Au-delà de l'incertitude prosopographique, l'étude de cas montre l'hétérogénéité des syllaniens et les limites des pouvoirs dictatoriaux, puisque Sylla échoua dans son entreprise. Enfin, en dépit de la rapidité de la colonisation syllanienne et du respect des procédures, A. Keaveney ( Paludes et Silvae: the Ruin of the Veteran ») en pointe les problèmes : confusion, fraude, octroi de terres ingrates pour certains vétérans et réservation des meilleures terres à d'autres. La portée et la réussite de cette colonisation sont relativisées.

F. Santangelo ( Sulla in the Bellum Jugurthinum ») inaugure la deuxième partie consacrée à la réception avec une holistic and discursive exploration (p. I07) du portrait dressé par Salluste. Plusieurs thèmes sont privilégiés comme l'éloquence, ses capacités de commandement, tout en met- 
tant l'accent sur les techniques narratives utilisées par l'auteur pour mettre en scène le jeune Sylla au cœur du conflit. Cette approche littéraire est poursuivie dans une perspective intertextuelle et comparatiste par J. A. Rosenblitt (« Sulla’s Long Shadow : Sallust in Tacitus and Tacitus in Sallust »). Les Histoires de Salluste explorent les conséquences de l'action syllanienne sur la res publica comme les Annales de Tacite montrent celles du pouvoir augustéen sur le Principat. Les deux dernières contributions soulignent l'image négative de Sylla. Le patricien est considéré comme un exemplum de la cruauté, de la violence et de la tyrannie. L'historiographie grecque est au cœur de l'article de I. N. I. Kuin (« Sulla and the Philosophers : the Cultural History of the Sack of Athens "). Les relations de Sylla avec la paideia, la littérature, la philosophie et le monde grecs constituent une part conséquente de la construction mémorielle du personnage. Le philhellénisme romain est présenté comme une stratégie culturelle et la destruction du patrimoine culturel perdure à travers les siècles comme une marque de barbarie. Enfin, A. Eckert (“Reconsidering the Sulla Myth ») revient sur l'affirmation considérant que la vision d'un Sylla cruel et tyrannique ne serait apparue que dans les années 40 pour U. Laffi ou sous Auguste pour F. Hinard. Or l'image négative existait déjà dès son vivant et elle ne saurait être un mythe. A. Eckert reprend le dossier, en s'appuyant surtout sur le corpus cicéronien, sur le topos contemporain de la crudelitas, puis sur le large consensus populaire existant pour abroger les réformes syllaniennes.

Pour conclure, ces études de cas apportent des éclairages précis contribuant au renouveau des études syllaniennes à l'œuvre depuis plusieurs années. D'ailleurs, la bibliographie à jour intègre des travaux collectifs récents sur le dictateur.

Cyrielle LANDrea

Université Bretagne Sud cyrielle.landrea@univ-ubs.fr
Lisa Maurice, Screening divinity,

Edinburgh, Edinburgh University Press, 2019, 228 p., £ 75.00 / ISBN 978I4744/25735.

La très prolifique série de publications “Screening Antiquity», publiée chez Edinburgh University Press, a accueilli en juin 2019 la monographie de Lisa Maurice, professeure et spécialiste de la réception de l'Antiquité de l'Université Bar-Ilan (Israël), Screening Divinity. Il s'agit d'un ouvrage s'intéressant à la représentation du divin à l'écran, que ce soit dans les traditions gréco-romaine ou judéo-chrétienne. Cette démarche est plutôt novatrice car elle a été peu abordée dans son ensemble, à la faveur d'articles publiés de manière hétérogènes sur tel film ou tel sujet historique ou mythologique.

L'ouvrage de 200 pages est divisé en huit parties mais, de manière assez dommageable, ne propose que i6 images, certaines d'assez mauvaise qualité en noir et blanc. La première partie, introductive, pose le débat historiographique, la problématique et la méthodologie de l'auteure et les limites de l'étude: absence des films muets et sur l'Islam et une concentration sur les productions américaines et anglaises.

La deuxième partie s'intéresse au concept d'anthropomorphisme à l'écran, presque obligatoire pour un art visuel, bien que les entités divines puissent prendre d'autres formes. Qu'elle soit celle des monothéistes ou des polythéistes, la puissance divine est toujours représentée de la même façon, selon des canons littéraires et artistiques antérieurs à la production envisagée. Divers éléments sont pris en compte dont celui du personnage de Jésus, souvent représenté à l'occidentale (blond, yeux bleus) ou la nature patriarcale d'un Zeus ou Dieu vieux, à la barbe blanche.

Les chapitres 3 et 4 abordent justement les caractéristiques physiques du Divin, Zeus et Hadès d'abord et leurs « référents ». Dans leur représentation au cinéma, il existe donc un fossé entre Dieu/Zeus et Hadès/ 
Satan, avec çà-et-là les choix ambitieux des scénaristes comme dans le film Bruce Tout Puissant ou dans la série Troy: Fall of a City, ayant irrité les puritains : en effet, dans ces deux cas, la divinité n'est plus représentée par la sacro-sainte carnation blanche. Une étude par dieu grec est ensuite développée, souvent issue du même échantillonnage de films (Clash of Titans, son remake et sa suite; Immortals, Percy Jackson...). Sans surprise, Zeus et son frère des Enfers exceptés, les autres Olympiens intéressent peu et lorsqu'ils sont présents à l'écran, ils sont standardisés. On regrettera que ces chapitres ne soient qu'une succession de descriptions, et que l'analyse conclusive soit peu développée.

Les chapitres 5 et 6 suivent la logique des deux précédents en présentant les représentations féminines. Du côté grec et romain, les déesses les plus présentes à l'écran (Athéna, Héra, Aphrodite et dans une moindre mesure Artémis) sont créées à l'image des actrices, souvent iconiques, qui les incarnent. L. Maurice démontre parfaitement que, à l'écran, les mouvements féministes et les prises de conscience en matière de gender roles ne suffisent pas encore pour présenter la déesse antique autrement. Du côté judéo-chrétien, l'auteure fait appel à la Vierge Marie et à Marie-Madeleine. S'il est possible d'associer la première au monde divin, il semble plus difficile de le faire pour la seconde. Malgré tout, c'est par ces deux personnages que l'on constate le mieux un changement du rôle de la femme dans notre société, grâce à une relecture plus moderne de la femme que ce n'est le cas pour les divinités polythéistes.

Le chapitre 7 présente les différentes formes de communication à l'œuvre entre le divin et les mortels : miracles, théophanies, épiphanies, prophéties, prières et divinations. Elles définissent, par essence, le degré de “ visibilité » des divinités à l'écran mais aussi entre les personnages.
Le dernier chapitre s'articule autour de deux façons de brouiller les pistes entre les mortels et les dieux, l'Apothéose et le déicide, depuis Hercule jusqu'à Jésus. D'une certaine façon, il est presque question ici pour L. Maurice de démontrer que les scénaristes (donc inconsciemment les spectateurs) cherchent à faire prévaloir l'humain/le mortel sur le divin/l'immortel, bien que le premier soit destiné à mourir et renaître alors que le second semble immortel par nature mais peut finalement mourir par la main de l'Être Humain.

La conclusion de l'ouvrage aurait mérité d'être présentée en introduction tant elle revient sur la production des péplums dans le temps. L'ouverture faite sur la série The Handmaid's Tale permet de réactualiser la question de la religion à l'écran et les rapports qu'entretiennent mortels et divinité.

Des films qui ne sont pas des péplums sont convoqués tout au long de l'ouvrage, ce qui est fort agréable. On pourra regretter quelques oublis ou approximations, qui n'enlèvent rien à la qualité de la réflexion, mais qui auraient pu contribuer à enrichir l'analyse. Dans une recension récente de son ouvrage, il était reproché à L. Maurice de ne pas parler d'Arès dans Wrath of the Titans (2012), qui a vu dans ce film son plus grand rôle ; il aurait été aussi intéressant de l'envisager, par exemple, dans l'adaptation cinématographique de Wonder Woman (Pattty Jenkins) en 20I7, dans laquelle ce dieu est interprété par David Thewlis, le Remus Lupin des films Harry Potter. La lecture de l'ouvrage de L. Maurice est donc à recommander comme point de départ à de nouveaux développements sur la représentation du divin à l'écran.

Mathieu Scapin

Musée Saint-Raymond, Musée d'archéologie de Toulouse mathieu.scapin@gmail.com 
Friedrich MeIns, Paradigmatische Geschichte: Wahrheit, Theorie und Methode in den Antiquitates Romanae des Dionysios von Halikarnassos, Stuttgart, Franz Steiner Verlag, 20I9, I69 p., 44€/ ISBN 97835I5I22504.

Meins's monograph on compositional theory and methodology in Dionysius of Halicarnassus' Antiquitates Romanae fills a gap in German scholarship, introducing the concepts underlining the rhetorical framework of D.'s history of Rome. As a first work based on a PhD thesis it is sound: the prose is taut and the text is generally well constructed; it zips by as M. introduces readers to developments in Dionysian studies. But for those familiar with D.s works and secondary literature it is frustrating.

There are four chapters, as well as an introduction and a useful conclusion. There is neither a Stellenregister nor an index, evidence (amongst more) of a rush to press. URLs and works unconnected to M.'s argument litter the bibliography.

M.s first chapter broadly surveys D.s scripta rhetorica and the Antiquitates, placing D. within Greek historiography and identifying his notion of truth, and considers whether rhetoric is a structuring principle in his work. Practically, this means quoting D's explicit statements, usually in De Thucydide and the Epistula ad Pompeium. M. also reiterates key concepts:

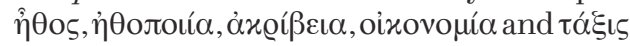

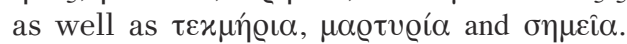
The chapter ends with a short discussion of D.s rejection of mythology limited to book $\mathrm{I}$, the first sign that $\mathrm{M}$. is not wholly in control of the historical material. There is no indication that M. will discuss a similar topic in his third chapter, which contains the material needed earlier, particularly D.s statements at the start of book 2. The absence of a necessary discussion of the theophany of the Dioscuri in the Forum at 6.13 is perplexing.
The second chapter concerns plausibility and appropriateness as criteria for truth in historiography. Here the focus is on $\mu$ í $\mu$ $\sigma \varsigma$

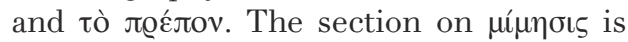
underdeveloped given its noted prominence since at least Tim Whitmarsh's essential (and uncited) 200I 'Greek Literature and

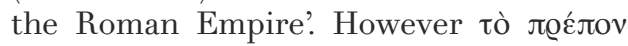
is engaging. In chapter three M. looks to understanding idealised history and ideals in D.'s narrative, initially using Matthew Fox's scholarship to spark his own thoughts

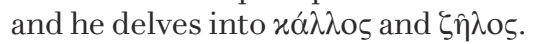

In this - and throughout the book - M. cites Goudriaan's ig89 'Over Classicisme' as a pathfinder, but finds himself stuck in his predecessor's footsteps. Indeed Goudriaan traces the same terms and ground as M., before an analysis of the Antiquitates. As a result, an unfortunate atmosphere of deja vu pervades, as M. broadly follows Goudriaan's

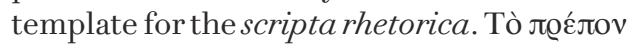
aside, Goudriaan's readings are the more sensitive.

In chapter 4 we finally get to the issue of paradeigmata and exemplarity, a necessary area of research, as trail-blazed by Matthew Roller and Rebecca Langlands, especially in Roller's 2004 'Exemplarity in Roman Culture'. Neither output is known to M.

It is here that M.s unpreparedness is in evidence. No fragment from books $12-20$ is cited, full of relevant moral material collated by Byzantine excerpters and epitomisers. Much else goes unmentioned. M. lacks for discussions of Cloelia, Cincinnatus, K. Quinctius, Romilius, Laetorius Mergus, Postumius' embassy to Tarentum, Siccius Dentatus, or Fabricius on Roman exemplarity. Each would have assisted M.s theme. The discussion of Menenius Agrippa is welcome but curt given the vast bibliography on his metaphorical speeches. The words of L. Valerius in book II likewise should not have been reduced to an oblique footnote given their importance to M.'s topic. 
This is a shame as in this chapter M. writes with vim and breaks new ground. Here there is the kernel of an excellent article. This is all to say that while M.'s discussion of

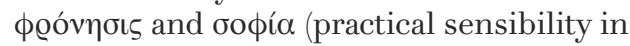
politics) is a sound contribution, this means little if he does not connect more dots and provide evidence of that sensibility in action in the Antiquitates.

On the other hand M.'s approach to the Isocratean influence on D. is encouraging. To date most scholars have, in noting D.'s debt to Isocrates, simply suggested that

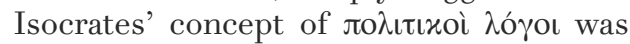
essential to D.s own practical notion of rhetorical historiography. M. applies these ideas to D.'s depiction of constitutional change. He surveys Romulus' constitutional debate at Rome's foundation, the expulsion of the Tarquins, the constitutional speech of Manius Valerius (7.54-6), and ignores the consular tribunate.

Finally M. considers the applicability of speech as a didactic function in the Antiquitates honing in on an episode in the first secessio plebis.

M.'s work is based on his 2014 thesis Rhetorische Theorie, literarische Kritik und historische Methode bei Dionysios von Halikarnassos, a more accurate reflection of this monograph. The new title is a nod to its fourth chapter, a tacit acknowledgement that this is where readers will find most material of note. However by naming the Antiquitates the problem is thrown into sharp relief: it becomes plain through this book that the Antiquitates are not a text that M. is familiar with. Their associated literature is foreign to him. This is also true of related fields, especially rhetoric in historiography. This issue is unwittingly signalled in M.'s introduction as he demands an "unbiased discussion" (unvoreingenommene Diskussion) that does not assume an apriori relationship between rhetoric and historiography (p.I5-16). Without Luce, Moles, Woodman or Wiseman - the field's cornerstones
- M. ploughs on. It is an attitude that characterises the text throughout.

Simply put, M. does not supply the evidence to ground his arguments more firmly, despite his strengths. In this slim volume there is little for readers to be swayed to M.'s perspective. M.'s D. is mostly contextless, both historically and critically; the comparandum of Livy is barely present, and his knowledge of many aspects of importance is spotty. The Antiquitates are mostly absent.

Yehudah Gershon University of Roehampton / Universität Potsdam yehudah.gershon@roehampton.ac.uk

Pier Giuseppe Michelotтo, $D a$

Pietroburgo a New Haven. Sei saggisu M.I. Rostovtzeff, Milan et Turin, Bruno

Mondadori, 20I9, 369 p., $22 € /$

ISBN 9788867742264.

Les lecteurs d'Anabases connaissent bien et M. I. Rostovtzeff et P. G. Michelotto. Le premier est un immense savant qui a laissé une trace majeure dans les sciences de l'Antiquité de la première moitié du $\mathrm{xx}^{\mathrm{e}}$ siècle; le second est un collègue émérite de l'université de Milan qui a consacré une grande partie de ses travaux à analyser l'œuvre du premier et qui en est un des interprètes les plus avisés et les plus fins. Les six essais ici publiés, qui sont pour certains quasiment une monographie, sont le fruit de cette rencontre; ils s'avèrent passionnants à lire ou relire. Car il s'agit bien de six travaux déjà publiés, entre 1999 et 20I8, vingt ans passés à scruter les facettes principales d'une œuvre tentaculaire et puissante, qui a fait l'objet d'une véritable redécouverte dans les dernières décennies du $\mathrm{xx}^{\mathrm{e}}$ et au début du Xxi ${ }^{\mathrm{e}}$ siècle.

Parmi les six essais reproposés figure l'analyse de Mystic Italy qui a paru, en 2005, 
précisément dans Anabases, mais dont une version longue, publiée en 200I, est ici rééditée. Dans sa brève présentation initiale (p. viii-x), P. G. Michelotto précise bien que ses travaux n'ont pas fait l'objet d'une révision; seuls quelques ajouts bibliographiques sont signalés entre crochets. Là n'est évidemment pas l'intérêt de cette monographie; ce qui la rend précieuse, c'est l'ampleur des thématiques, des aires et des périodes touchées par Rostovtzeff, et le tableau général de l'Antiquité qui en émerge, nourri par une érudition sans pareil et une authentique vision des dynamiques politiques, sociales, économiques, culturelles et religieuses qui ont animé la Méditerranée antique, de l'époque hellénistique à l'époque romaine. Pour rendre compte de ces transformations complexes dans la longue durée, Rostovtzeff a produit des synthèses d'une rare acuité, servies par une narration séduisante, soustendues par une armature conceptuelle précise, nourries par le spectacle du présent, celui de la révolution russe, des avancées de l'économie capitaliste, des migrations et des colonialismes. La pensée de Rostovtzeff est moderne, ce qu'on a pu lui reprocher, dans le sens où il ne craint pas l'anachronisme, l'analogie, les rapprochements audacieux, voire discutables. Habité par des convictions fortes, il a produit une œuvre originale, qui ne laisse personne indifférent et qu'il faut lire et relire.

Comprendre aujourd'hui cette œuvre, contextualiser la pensée de Rostovtzeff, en comprendre les ressorts, cerner les influences qu'il a reçues et celle qu'il a luimême exercée, retracer les débats, parfois âpres, que ses publications ont suscités demande un guide expert. P. G. Michelotto l'est plus que quiconque, de sorte qu'on se réjouit de voir ici réunis six apports majeurs à l'historiographie rostovtzeffienne. Dans l'ordre, il approche d'abord la réflexion du savant russe en matière d'histoire économique, en examinant le cas de l'Égypte hellénistique et romaine (p. I-IO4); il traite ensuite de Mystic Italy, paru en 1928 et abordé comme une œuvre "anormale » (p. Io5-138); vient alors l'analyse de six lettres envoyées par Rostovtzeff au magazine Zveno, en I923, d'Italie, qui éclairent les avancées des connaissances sur le monde ancien, mais qui jettent aussi une lumière intéressante sur le contexte italien contemporain, notamment sur le fascisme (p. I39-2I2); le quatrième essai tourne autour de deux lettres inédites de Rostovtzeff à Arthur S. Hunt, datant de I929, et relatives aux trouvailles de DouraEuropos, en particulier un parchemin (p. 2I3-237), ce qui permet de suivre le travail de déchiffrement au plus près du texte; c'est en revanche le travail d'édition et de réédition de la Social and Economic History of the Roman Empire qui se trouve au centre du cinquième essai (p. 239-277), abordé sous l'angle de la “démolition d'un chef d'œuvre »; enfin Rostovtzeff et Auguste, et plus largement la monographie intitulée $L a$ naissance de l'Empire romain, consacrée en I9ı8 aux guerres civiles romaines et à leurs conséquences politiques, sont au cœur du sixième et dernier essai (p. 279-295).

Le volume se termine par une riche bibliographie (p. 299-369). On peut regretter l'absence d'un index dans la mesure où le volume, bien que centré sur une œuvre, est extrêmement foisonnant. Il se lit de bout en bout avec un intérêt sans cesse renouvelé. Historiens de l'Antiquité, spécialistes d'archéologie ou de papyrologie, historiens des religions et des représentations, spécialistes des processus économiques et des évolutions sociales, mais aussi historiens du début du $\mathrm{xx}^{\mathrm{e}}$ siècle, spécialistes des réseaux savants et de l'archéologie des savoirs trouveront dans ces 369 pages des analyses d'une rare profondeur, fruit de la fréquentation assidue de la pensée fascinante du grand Rostovtzeff, au demeurant ami fidèle de l'aussi grand Franz Cumont, avec lequel il entretint un dialogue fécond, notamment autour des fouilles conjointes de Doura- 
Europos, comme en témoigne leur correspondance publiée en 2007 (volume qu'il aurait sans doute été utile d'ajouter à la bibliographie finale). On ne peut que souhaiter que P. G. Michelotto poursuive ses enquêtes sur le savant russe.

Corinne Bonnet

Université Toulouse - Jean Jaurès Corinne.bonnet@univ-tlse2.fr cela à Hérodote et Thucydide (même si la question de la circulation des modèles n'est pas directement abordée), l'œuvre de l'annaliste chinois Sima Qian, le Shi Ji, est ainsi présentée et discutée. Selon l'auteur, cette histoire critique naît, en Grèce, de l'émulation entre les historiens et les autres experts du savoir (sophistes, philosophes, médecins), tandis qu'en Chine, elle est le produit d'un rapport dialectique à l'histoire monarchique traditionnelle.

La première section est consacrée aux récits héroïques, et travaille de façon remarquable la notion d'histoire intentionnelle. M. Węcowski aborde les récits fictifs inventés par Ulysse ou Athéna dans l'Odyssée et montre qu'ils peuvent se lire comme des projections de la société contemporaine d'Homère à l'intérieur du monde héroïque. Dans cette forme de "distanciation de l'effet de distanciation » épique (p. 29), l'auteur décèle un “présent intentionnel » inséré dans le passé mythique et participant de la reconnaissance d'une identité partagée par le public d'Homère. M. Nafissi étudie ensuite les scènes représentées sur le trône d'Apollon à Amyclées, dont l'iconographie témoigne de l'ancienneté de l'austérité spartiate, fondamentale dans l'identité lacédémonienne, et forme bien un exemple “d'histoire picturale intentionnelle». Toutefois, la façon dont l'auteur justifie la présence de personnages a priori peu pertinents pour l'histoire et la culture laconiennes au centre de la frise (Thésée ou Démodocos), dont la représentation suggèrerait un contraste critique avec les valeurs spartiates, paraît peut-être un peu trop systématique.

Riche de quatre contributions, la section sur Hérodote et son héritage s'ouvre avec l'article de M. Giangiulio, qui réévalue l'importance des récits oraux traditionnels au sein des Histoires et défend leur historicité générale, par opposition à leur factualité de détail. N. Luraghi étudie ensuite l'arrièreplan historique des révoltes égyptiennes 
contre les Perses. Les interventions athéniennes en faveur des Égyptiens au milieu du $v^{\mathrm{e}}$ siècle expliquent la familiarité d'Hérodote avec ces épisodes, visible dans plusieurs allusions bien relevées par le chercheur. Plusieurs pistes, quoique spéculatives, sont de premier intérêt, à l'instar de l'hypothèse selon laquelle Hérodote aurait eu le projet de poursuivre l'histoire de l'Égypte achéménide jusqu'au milieu $\mathrm{du} \mathrm{v}^{\mathrm{e}}$ siècle, avant d'intégrer ses recherches au sein du logos égyptien. La thèse défendue dans la contribution suivante, due à J. C. Bernhardt, fait d'Hérodote l'une des sources du deuxième livre desMaccabées. Après une remarquable revue de la littérature consacrée à ce livre, J. C. Bernhardt juxtapose plusieurs points de comparaison indiquant la façon dont l'auteur du livre a remodelé le schéma actanciel des Histoires: les héros sont désormais les Juifs, tandis que les Grecs séleucides sont comparés aux barbares perses d'Hérodote. Enfin, l'article d'A. Free paraît un peu plus isolé dans la section; il y est question des Longues Vies du pseudoLucien, utilisées, dans une périodisation chronologique très large allant jusqu'à l'Antiquité tardive, pour dresser une typologie des pratiques de lecture savante et de sociabilité aristocratique à l'époque impériale.

La dernière section aborde les problématiques plus générales de la philosophie de l'histoire et de la mémoire. L'ambitieux article de K. Wojciech réfléchit à l'adaptation des trois types d'oubli distingués par Ricœur (mémoire obligée, mémoire empêchée, mémoire manipulée) à la société athénienne classique et au corpus des orateurs attiques. La chercheuse montre l'importance de certains événements (la fin de la guerre du Péloponnèse, la révolution oligarchique de 404-403) dans ces formes d'oubli collectif, que les orateurs pouvaient encourager ou, au contraire, remettre en question. Enfin, l'article de V. Schulz, le seul à se pencher sur l'historiographie latine, interroge la façon dont les historiens et biographes du Haut Empire intégrèrent l'oubli à leur projet littéraire. Cette démarche l'amène à distinguer de façon intéressante, mais peut-être un peu attendue, différentes stratégies des auteurs pour « faire oublier », selon qu'ils pratiquent l'histoire annalistique ou la biographie. Cependant, la définition sémiotique très large de l'oubli adoptée ne paraît pas toujours opérante: qu'est-ce qui, en effet, distingue in fine l'effacement, par Tacite ou Suétone, de l'image positive de Néron ou de Domitien des pratiques de manipulation du lecteur ou d'insinuation, aujourd'hui bien connues des philologues, en particulier tacitéens?

L'ouvrage se termine par un "épilogue » dans lequel F. K. Maier défend le rôle de la littérature pour aider le lecteur à ressentir la "nature profonde» (Wesenhaftigkeit) de l'histoire, un sentiment que l'histoire académique échouerait à transmettre. La contribution fournit des pistes de réflexion passionnantes, et donne ainsi une excellente conclusion d'ordre général à l'ouvrage. On regrettera peut-être une bibliographie qui ignore les progrès récents de l'histoire contrefactuelle, ou les travaux importants de Ricœur dans Temps et récit. 3. Le temps raconté, sur les liens profonds entre "fictionnalisation de l'histoire » et “ historicisation de la fiction ».

En somme, quoique bref, l'ouvrage édité par A. Möller propose, en trois sections dotées d'une forte cohérence interne, un vaste panorama chronologique et thématique et plusieurs perspectives stimulantes sur le statut de l'histoire et de la mémoire dans les mondes anciens.

Louis Autin

Sorbonne-Université ls.autin@gmail.com 
Helmut Pfeiffer, Irene Fantappiè, Tobias Rотн (éds.), Renaissance Rewritings,

Berlin et Boston, De Gruyter, 20I7, 79,95 €/ ISBN 9783iго5223о3.

Cet ouvrage réunissant quatorze contributions en anglais a eu pour base trois événements scientifiques organisés entre 2014 et 2015 dans le cadre d'un projet collaboratif soutenu par le Centre de recherche 644 "Transformations de l'Antiquité » de l'Université Humboldt de Berlin. Le projet avait pour titre complet: " Transformations of Antiquity in Italian and French Early Modern Literature (I450-I59o)». Irene Fantappiè, qui signe l'introduction du livre, assigne à celui-ci deux buts: une réévaluation de la notion de « réécriture » (rewriting), dont l'éditrice remarque qu'elle est vague et qu'elle n'est plus problématisée ; proposer de nouvelles interprétations de quelques textes (et contextes) cruciaux de la littérature de la Renaissance française et italienne. Ce deuxième objectif assure à l'ouvrage une unité de principe. Mais comme la réflexion sur la réécriture domine, cette unité est un peu affaiblie par des articles qui l'affrontent moins directement. La division en deux parties, une qui serait plus théorique et intitulée seulement Rewriting et l'autre, faite de cas d'étude, Rewritings in Early Modern Literature ne paraît pas absolument indispensable, ne serait-ce que parce que des textes à teneur assez théorique se trouvent dans la deuxième partie. L'ensemble de l'ouvrage ne fournit pas moins une lecture de grand intérêt, et une autre sorte d'unité est acquise d'un point de vue formel par la structuration explicite et, peut-être, la limitation en longueur des articles ; cela assure à une grande majorité d'entre eux une clarté et une efficacité remarquables. Le deuxième objectif défini par Irene Fantappiè est ainsi d'autant mieux atteint que des présentations et des mises au point précises sont fournies pour chacune des œuvres abordées par les différents auteurs (ne pouvant les citer tous ici, je renvoie à la table des matières de l'ouvrage que l'on trouve sur le site de l'éditeur: https://www.degruyter.com/ view/title/524805): par-delà leur diversité, l'ouvrage pourra ainsi profiter également à de jeunes chercheurs'ses ou à des chercheurs'ses qui se seraient récemment orienté·es vers la littérature de la Renaissance.

Mais venons-en à la notion centrale - la réécriture - et aux apports importants de l'ouvrage en matière d'intertextualité. Dans son ensemble, et en particulier grâce à des textes qui alimentent directement ce questionnement, l'ouvrage propose plusieurs sortes d'avancées: la première, sur laquelle Irene Fantappiè ouvre son Introduction et qu'elle associe à la notion de “transformation » qui était au cœur du projet, consiste dans la bi-directionnalité à apprécier dans les phénomènes de réécriture. L’œuvre “ cible » réécrivant une œuvre « source » est évidemment modifiée (enrichie, complexifiée...) par elle mais elle la modifie également: la contribution de Nina Mindt dédiée à l'Eroticon de Tito Vespasiano Strozzi et à sa relecture - sinon réécriture-de toute l'histoire de la tradition de l'élégie latine (en particulier de l'élégie antique) se situe le plus explicitement dans cette perspective. Et c'est une perspective vraiment stimulante; en tant qu'étude de l'“histoire littéraire immanente» ou réflexion sur la façon que les textes (sinon les auteurs) ont de constituer leur tradition "pertinente", elle n'est pas exactement nouvelle, et on peut peut-être regretter que la dimension proprement bi-directionnelle des rapports entre les textes n'ait pas été davantage illustrée ou re-discutée. L'article qu'Irene Fantappiè consacre à Pietro Aretino et où elle étudie en particulier, sous l'angle de la réécriture, l'ouverture de la seconde journée du dialogue érotique Dialogo (I536) pose quant à lui les bases d'un type d'approche que rejoignent quelques autres contributeurs et qui ouvre des pistes 
vraiment intéressantes; elles pourraient être transférées à d'autres auteurs, d'autres époques (à commencer par les Anciens eux-mêmes), même si l'on comprend aussi que la spécificité de la Renaissance soit ici considérable - en l'occurrence et en définitive, cela a à voir avec la façon dont Pietro Aretino se constitue en auteur, et en auteur d'un nouveau genre. Ce que propose Irene Fantappiè est de se placer au-delà ou à côté des phénomènes d'intertextualité pour observer plutôt des dynamiques d'interauctorialité. En ce qui concerne Aretino et son Dialogo, elle s'emploie à démontrer comment dans cette œuvre “Aretino », dont la propre figure auctoriale même apparaît comme une création au second degré, s'approprie en l'adaptant la figure auctoriale d'un auteur de l'Antiquité dont il ne reprend pas les mots et qu'il ne mentionne même que rarement: Lucien, et le Lucien de l'édition de N. Zoppino de i525 (c'est-à-dire apte à devenir un représentant du serio ludere) et, plus spécifiquement encore, le Lucien de l'Histoire Vraie. Au cours de son étude, Irene Fantappiè a des observations très stimulantes et son invitation I) à creuser ces dynamiques inter-auctoriales 2) à analyser les phénomènes de ce qu'elle appelle refiguring demande sans doute à être suivie. La contribution de Clément Godbarge sur Ippolito de Medici et son appropriation de la figure d'Hippocrate témoigne ainsi, à sa manière, de l'intérêt de ce type d'enquête. Enfin, parmi les différentes formes de réécriture illustrées dans les contributions, une autre qui donne lieu à des analyses particulièrement saisissantes concerne la réécriture de ses propres écrits (favorisée par l'époque, est-il souligné à plusieurs reprises) : la réflexion menée par Manuele Gragnolati sur le cas particulier de la reprise par Dante de ses poèmes lyriques dans le recueil de la VitaNuova en est, de mon point de vue, le plus bel exemple, étant donné les outils conceptuels que le chercheur reprend et s'approprie lui-même dans cette étude et le renouvellement de l'approche de la relation entre les œuvres que cela permet visiblement.

\author{
Séverine TARANTino \\ Université de Lille \\ severine.tarantino@univ-lille.fr
}

Charlayn von Solms, $A$ Homeric

Catalogue of Shapes. The Iliad and

Odyssey Seen Differently, Londres,

Bloomsbury Academic, 2019, 3o6 p.,

$£ 85$ (hardback), £28,99 (paperback) /

ISBN 978I35oo39582 (hardback), 9781350I9457 (paperback).

Ce quatrième opus de la collection Imagines - Classical Receptions in the Visual and Performing Arts, qui aborde le monde antique au prisme d'approches contemporaines, est consacré à la démarche réflexive de Charlayn von Solms, artiste sud-africaine, qui a réalisé une série d'assemblages dédiée à l'Tliade et l'Odyssée, A Catalogue of Shapes. La plasticienne se définit comme constructiviste dans la “Préface». Elle y présente sa méthode : l'assemblage d'objets du quotidien pour composer des artefacts signifiants, soit une démarche imbriquant une dimension conceptuelle et une approche technique. Elle l'utilise pour appréhender l'oralité de la poésie homérique et son style formulaire, tels qu'analysés par G. Nagy et L. Muellner notamment. En effet, les aèdes s'appuient sur des techniques et formules préétablies pour créer une œuvre nouvelle, comme l'artiste choisit des objets selon des caractéristiques matérielles et visuelles, équivalents plastiques de l'épithète homérique ou de la composition poétique. Cette comparaison justifie ce projet éditorial original, qui comprend une réflexion esthétique sur l'art homérique, le catalogue des douze sculptures et une invitation à lire ces assemblages à la manière d'un rhapsode. L'introduction 
approfondit ce parallèle entre la méthode de composition de l'épopée, à partir de la combinaison de personnages récurrents, de formules et de motifs types et celle de la plasticienne, à partir de l'assemblage de formes, de matières et de couleurs. L'articulation entre la technique utilisée et la signification finale est fondamentale : la réception de l'épopée homérique évolue dans le temps, selon des critères anthropologiques, socio-culturels et géographiques, ce qui amène à la nécessité d'une traduction rendant compte en même temps de sa compréhension.

C'est le projet de von Solms qui en élabore une traduction dans un autre medium, la sculpture, par la composition d'une galerie de portraits de personnages de l'épopée. C'est pourquoi elle invite son lecteur à "voir différemment » et à considérer $A$ Catalogue of Shapes comme une étude homérique à part entière. L'analyse des descriptions poétiques amène à celle du régime de visualité du monde épique et conduit à une réflexion plus globale sur l'évolution du rapport des artistes à la représentation et sur la diversité spatiotemporelle des modes de figuration et des traditions. L'artiste revient sur l'appréhension de l'objet homérique, en évoquant la référence à l'antique dans l'art contemporain médiatisée par une vision moderne de l'esthétique grecque qui valorise généralement les sujets figuratifs des $\mathrm{v}^{\mathrm{e}}$ et $\mathrm{IV}^{\mathrm{e}} \mathrm{s}$. avant J.-C. plutôt que les motifs géométriques archaïques. Cela conduit à questionner ce que l'objet d'art peut dire de l'epos, ce qui introduit l'idée de correspondances entre formes visuelles abstraites et personnages homériques au cœur du projet de la plasticienne et à la notion de composite object portrait comme traduction visuelle de la description homérique. Von Solms rappelle l'histoire artistique de cette notion depuis les célèbres portraits symboliques d'Arcimboldo à ceux de Picabia et s'inscrit dans la tradition de l'assemblage, tel que pratiqué par Picasso, Man Ray ou Damian Ortega.
Cela lui permet d'expliciter son usage d'objets pour signifier un trait de caractère. Les œuvres d'art ainsi créées impliquent des interactions entre forme et fond, artefact et spectateur, afin d'en décrypter le sujet, la composition et l'iconographie. Ces prolégomènes contextuels et méthodologiques aboutissent à la définition du Catalogue of Shapes comme this understanding of sculptural assemblage was combined with the notion of the 'composite object portrait' to create a series of sculptures based on twelve dramatic personae whose attributes and functions in the plot to elucidate Homer's principal heroes and their epics (p. 54). La série est alors replacée dans la tradition iconographique homérique : un panorama est dressé distinguant les représentations paradigmatiques d'Homère, depuis la période hellénistique à l'Apothéose d'Homère de Paolini, de celles des épisodes et personnages, de la période archaïque à Twombly, comme autant de transpositions visuelles des spécificités narratives et des modes de composition de l'épopée. La série d'assemblages relève dès lors de cette tradition tout en rendant compte de l'esthétique et de la composition du texte. La mise en abîme du travail poétique dans le «catalogue of Ships » du chant II de l'Tliade devient le modèle du “ catalogue of Shapes » : les comparaisons, parataxes, allusions et énumérations caractéristiques du texte homérique deviennent des associations de formes, de positions, de couleurs et de matières dans les sculptures. La série se fait ainsi un catalogue épique en deux catégories, figures de l'Odyssée et celles de l'Iliade, et quatre sous-catégories, les guerriers (Ulysse et Télémaque, Achille et Hector), les épouses (Pénélope et Hélène), les divinités (Calypso et Circé, Éris et Até) et les rois (Nestor et Ménélas), dans un réseau d'interrelations créant des effets de complémentarité et de contraste. Cette démarche réflexive de l'artiste sur son œuvre et sur son rapport à la tradition permet au lecteur d'apprécier pleinement le catalogue des douze sculp- 
tures (disponible en ligne : https://charlaynvonsolms.com/the-layout-of-a-catalogue-of-shapes). Ainsi, le jaune prédomine le groupe iliadique en référence aux cheveux d'or d'Achille et l'orange celle d'Ulysse par allusion à la peau tannée par les voyages, tandis qu'un même mode de composition en deux registres est utilisé pour traduire la métrique poétique. L'assemblage Odysseus MHTI $\Sigma$, par exemple, est composé d'objets évoquant son nostos (bouée, glissière de parapluie, gouvernail, arc) et sa ruse par leur imbrication : les attributs plastiques choisis génèrent l'image du marin expérimenté et épuisé qui rentre chez lui. Ce catalogue conduit à une synthèse sur ces " portraitsobjets », dont la matérialité structurelle, formelle et chromatique équivaut aux procédés poétiques. Ce n'est pas seulement une traduction, mais aussi une interprétation sélectionnant les attributs pour susciter les images mentales liées à ces personnages et à leurs aventures : comme dans l'Iliade et l'Odyssée, le spectateur doit reconstruire le réseau de significations, narratif, relationnel et thématique, de chaque élément du catalogue, les uns par rapport aux autres et dans leur ensemble. Enfin, la conclusion résume la démarche de l'artiste et insiste sur l'expressivité et la dimension herméneutique de toute traduction.

C'est donc un ouvrage qui expose une démarche originale, entre essai et catalogue, et passionnante par la transposition de l'art homérique en langage plastique contemporain et la réflexivité de l'artiste sur le processus de création de ses sculptures, replacées dans leur contexte épistémologique, culturel et artistique et dans leur ancrage à la tradition homérique, renouant in fine avec l'étymologie polysémique de la лoínoıs.

Clarisse Evrard École du Louvre clarisse.evrard@wanadoo.fr
Trinidad Tortosa (éd.), Patrimonio arqueológico español en Roma. «Le Mostre Internazionali di Archeologia » de IgII y Ig37 como instrumentos de memoria histórica, Rome, L'Erma di Bretschneider, 20I9, 640 p., 255 €/ ISBN 978889ı3

Depuis la fin des années I98o, les publications relatives à l'histoire de l'archéologie en Espagne n'ont cessé de se multiplier. Les travaux qui interrogent le devenir de la discipline en dehors de ses frontières nationales sont en revanche peu nombreux. Ce déséquilibre reflète, en fin de compte, la plus faible projection extérieure de l'archéologie espagnole aux xix ${ }^{\mathrm{e}}$ et $\mathrm{xx}^{\mathrm{e}}$ siècles si on la compare à celle d'autres grandes puissances comme l'Allemagne, la GrandeBretagne, ou la France. Il existe pourtant des pistes à explorer. Ce sont les résultats d'une enquête de ce genre que nous offre l'ouvrage collectif dont il est ici question et dans lequel est étudiée la participation espagnole aux expositions archéologiques organisées à Rome en I9II et I937: la Mostra Internazionale di Archeologia, qui se tint dans le cadre des célébrations du cinquantenaire de l'unité italienne - et qui visa donc, du moins en partie, à produire un discours destiné à légitimer l'existence du jeune État - et la Mostra Augustea della Romanità, qui se déroula dans un contexte politique bien différent, celui du régime fasciste de Benito Mussolini.

Ce volume est le résultat d'une vaste enquête dirigée par Trinidad Tortosa, chercheuse au Consejo Superior de Investigaciones Científicas (CSIC). C'est à ce titre qu'elle revient sur l'histoire, la méthode et l'esprit qui ont présidé à la réalisation d'un projet international ayant reposé sur une collaboration entre l'Espagne et l'Italie (p. 19-26). À bien des égards, cette entreprise prolonge et complète le livre publié il y a dix ans sur l'Escuela Española de Historia y Arqueología en Roma (Ricardo Olmos, Trinidad Tortosa et Juan Pedro Bellón Ruiz [éd.], Repensar la Escuela del CSIC en 
Roma. Cien años de memoria, Madrid, CSIC, 20Io), une École fondée en igio et dont l'une des premières missions fut précisément d'organiser la participation de l'Espagne à l'exposition de I9II.

Tant pour la Mostra Internazionale di Archeologia que pour la Mostra Augustea della Romanità, la contribution de l'Espagne se matérialisa par des envois conséquents. Il s'agit avant tout de moulages en plâtre, mais aussi de photographies et de dessins auxquels s'ajoutèrent, en I937, des plans et des maquettes. Offerts à l'Italie, certains de ces objets ont été retrouvés; il s'agit d'une cinquantaine de pièces conservées au Museo della Civiltà Romana. Naturellement, les envois firent la part belle à l'Hispanie romaine. Les copies d'objets provenant des anciennes provinces de Tarraconaise et de Bétique furent les plus nombreuses, mais les œuvres exhumées peu avant la tenue de l'exposition de ıgı par José Ramón Mélida et Maximiliano Macías dans la fouille d'Emerita Augusta (Lusitanie) ne furent pas oubliées. Elles permirent de souligner le dynamisme et la richesse de l'actualité archéologique espagnole d'alors.

L'un des objectifs de l'enquête était de parvenir à identifier le matériel envoyé en croisant les sources: archives institutionnelles, correspondances, coupures de presse, fonds photographiques, etc. Il s'agissait donc de retrouver l'organisation d'ensemble des salles espagnoles pour comprendre les choix qui motivèrent les envois, ce qui en dit beaucoup sur la façon dont le pays percevait sa propre identité et tentait de la diffuser. De ce point de vue, il est significatif que le royaume ibérique ne se contentât pas d'envoyer à Rome des objets relatifs à l'archéologie et à l'art de l'Hispanie romaine. Les organisateurs jugèrent nécessaire de joindre des témoignages du passé protohistorique péninsulaire, et en leur réservant une place d'honneur : en IgII, un moulage de la Grande Dame offrante du Cerro de los Santos fut placé au centre de la salle des provinces hispaniques. Parmi tous les pays impliqués dans la Mostra de I9II, l'Espagne fut, avec la Grèce, le seul pays à intégrer le passé préromain à son discours muséographique et identitaire. Trinidad Tortosa rappelle ainsi que les organisateurs avaient une idée très nette du discours qu'ils souhaitaient promouvoir à l'étranger. Intégrés à l'exposition, les Ibères, dont la culture était alors en voie de définition, devinrent un symbole de la fuerza y el interés de un mundo prerromano que se presentaba en Roma como base étnica del país (p.22). Le discours était aussi politique. Il témoignait des efforts faits par les partisans du regeneracionismo et du noucentisme (en Catalogne) pour donner de la visibilité aux avancées scientifiques du pays, à sa récente modernisation et à sa capacité à tourner la page de la crise de i898.

Les résultats de cette enquête sont offerts au lecteur sous la forme d'un épais volume de plus de six cents pages rassemblant vingt-sept études. Soulignons d'emblée une limite importante: son prix. Il faut débourser $255 €$ pour en faire l'acquisition. Ce genre de publication spécialisée n'a certes pas vocation à devenir un succès de librairie, mais un prix de vente aussi élevé ne peut que limiter davantage sa diffusion en ne permettant guère qu'aux seules institutions d'en faire l'achat. Pour le reste, la richesse du contenu et des illustrations, l'organisation du discours, les textes-bilans de présentation (prologue et introduction) et de conclusion (c'est bien la fonction des deux articles de la partie IV), sont parmi les points forts de ce beau volume.

Précisons que le titre du livre est quelque peu trompeur. La part réservée aux deux expositions est inégale. C'est bien la Mostra de igir qui est au centre du propos, l'exposition de 1937 apparaissant comme une sorte de prolongement de la précédente expérience. A priori, le rapprochement entre deux événements qui s'inscrivirent dans des contextes radicalement différents et leur traitement très déséquilibré pourraient faire perdre au livre un peu de son unité. 
On comprend toutefois les raisons qui ont conduit à faire ce choix. En IgII, la collection de moulages envoyée par l'Espagne ne fut pas prêtée mais offerte à l'État italien, de sorte que ces objets rejoignirent le Museo del Imperio Romano - inauguré en I929 - et furent en partie réutilisés pour la Mostra Augustea della Romanità. Or au-delà de l'étude de ces deux évènements politiques et culturels, l'identification des moulages et la récupération de ce patrimoine archéologique (copie d'antiques et maquettes) étaient deux des principaux objectifs de ce projet de recherche. Autrement dit, au-delà des expositions en elle-même, le véritable objet d'étude de ce livre est bien la collection offerte par l'Espagne à l'Italie. C'est elle qui est le véritable protagoniste du volume édité par Trinidad Tortosa et lui donne son unité et sa cohérence d'ensemble.

Nous ne saurions revenir en détail sur chaque article. Il nous a semblé plus pertinent d'en proposer une vue d'ensemble susceptible d'indiquer au lecteur ce qu'il peut espérer trouver à l'intérieur (une précision : notre commentaire ne suit pas toujours le plan de l'ouvrage, téléchargeable sur le site de l'éditeur).

La partie I (divisée en six sous-parties qui rassemblent dix-sept des vingt-sept études que comporte l'ouvrage) concerne la Mostra Internazionale di Archeologia de IgII. Six contributions reviennent sur les contextes scientifiques, politiques, institutionnels, culturels (y compris artistiques puisqu'un texte concerne l'implication de l'Espagne dans l'exposition internationale d'art de Rome, organisée elle aussi dans le cadre des fêtes du cinquantenaire) et muséographiques (le réaménagement des thermes de Dioclétien pour accueillir l'exposition) dans lesquels s'inscrivit la participation espagnole (textes de G. Mora, A. Balcells, J. M. Lanzarote, C. Caruso, I. Pietroletti, J. Sendra Mestre).

L'organisation de la salle consacrée aux provinces hispaniques est ensuite décortiquée à travers une série d'études complémentaires qui analysent le rôle tenu par les différentes institutions engagées dans cette aventure (Institut d'Estudis Catalans, Museo Arqueológico Nacional, musées archéologiques de Mérida et de Séville). Elles permettent d'identifier les objets envoyés dans la capitale italienne, que l'analyse prenne pour point de départ l'étude de l'institution à l'origine de l'envoi (textes de T. Tortosa et X. Aquilué, M. Moreno Conde et Á. Castellanos, J. M. Álvarez Martínez et T. Nogales Basarrate, M. Camacho Moreno et A. D. Navarro Ortega), la région d'où proviennent les originaux (B. Gamo Parras, C. J. Morán Sánchez, J. Beltrán Fortes) ou la spécificité du support d'origine des objets reproduits, comme l'épigraphie (L. Benedetti).

Enfin, trois biographies intellectuelles (T. Tortosa, A. Pizzo) complètent cette première partie en offrant au lecteur la possibilité de mieux connaître trois des quatre principaux acteurs de la participation espagnole à la Mostra de ıgı : Josep Pijoan, Josep Puig i Cadafalch et José Ramón Mélida (l'étude prévue sur Manuel Gómez Moreno n'a finalement pas pu être intégrée).

Bien plus courte (une introduction et deux textes), la partie II complète la précédente en revenant sur les liens Espagne-Italie dans le cadre de la Mostra Augustea della Romanità de ig37 (T. Tortosa, M. Martín Camino, A. Duplá). Organisée dans le cadre des célébrations du bimillénaire de la naissance d'Auguste, elle se déroula dans un contexte bien différent, celui de l'Italie fasciste et du basculement progressif de l'Espagne - alors en pleine guerre civiledans la dictature franquiste. Que ce soit du côté italien ou espagnol, le discours produit en I937 fut donc très différent : recentré sur l'Empire romain (la Protohistoire ibérique fut laissée de côté), destiné à souligner le rôle civilisateur et pacificateur de Rome, et présentant Franco et Mussolini comme de nouveaux Auguste. 
Si les deux premières parties présentent les résultats d'une enquête dont la finalité principale était de reconstituer le contenu de la salle Hispaniae lors des expositions de I9II et I937, la partie III se penche quant à elle sur le discours archéologique produit à travers deux supports très caractéristiques de la période et qui jouèrent un rôle majeur dans les deux évènements célébrés dans la capitale italienne : le moulage en plâtre et la presse. Trois contributions (J. M. Luzón Nogué, A. Campano Lorenzo, L. Ungaro) reviennent sur les collections de moulages de la Real Academia de Bellas Artes de San Fernando (Madrid), de l'ancien Museo Nacional de Reproducciones Artísticas (transféré en 20II au Museo Nacional de Escultura de Valladolid) et du Museo della Civiltà Romana. L'étude de ces deux derniers cas permet non seulement de réfléchir sur l'histoire et la fonction de ces collections de copies, mais aussi sur leur avenir. Enfin, deux articles (A. Comino et R. Liceras-Garrido, T. Tortosa) se penchent sur la couverture médiatique des deux expositions dans la presse écrite, aussi bien du côté espagnol (pour celle de I9II) qu'italien (I9I et I937).

Ajoutons pour terminer que le livre est accompagné d'une clé USB qui fournit des informations et des compléments utiles. Il s'agit de trois bases de données qui rassemblent et mettent en relation l'information récoltée: l'une sur les objets envoyés par l'Espagne aux deux expositions italiennes; la deuxième sur les archives émanant des différentes institutions organisatrices; quant à la dernière, elle concerne les coupures de presse exhumées des hémérothèques espagnoles et italiennes. On y trouvera également des ressources graphiques, la bibliographie citée dans les bases de données et les instructions d'utilisation au format Pdf. Ce sont là des compléments éminemment utiles, à condition toutefois de disposer de Microsoft Access. À l'heure des humanités numériques et du libre accès à l'édition scientifique, alors que les supports - humains et techniques - offerts aux chercheurs en sciences humaines se multiplient (pensons à la TGIR [très grande infrastructure de recherche] HumaNum [https:/www.huma-num.fr/]), il y a là, nous semble-t-il, un choix regrettable. Dans leurs propos de conclusion, Trinidad Tortosa et Lucrezia Ungaro évoquent les prolongements possibles de ce projet de recherche, en particulier l'organisation d'une exposition itinérante. La mise en ligne des trois bases de données pourrait en être un autre.

Les quelques limites que nous avons soulignées n'enlèvent rien à la qualité et à l'intérêt d'un beau volume issu d'un projet qui, nous l'espérons, permettra à terme de redécouvrir et de mettre en valeur le patrimoine archéologique espagnol conservé à Rome.

Grégory Reimond Casa de Velázquez, Université Toulouse - Jean Jaurès gregoryreimondı984@gmail.com 